\title{
Significance of Hydrogen as Economic and Environmentally Friendly Fuel
}

\author{
Shashi Sharma ${ }^{1,2}$, Shivani Agarwal ${ }^{1, *}$ and Ankur Jain ${ }^{3,4, *}$ (D) \\ 1 Department of Physics, JECRC University, Jaipur 303905, India; sharmashashi85@gmail.com \\ 2 Department of Physics, S.S. Jain Subodh P.G. College, Jaipur 302015, India \\ 3 Natural Science Centre for Basic Research \& Development, Hiroshima University, \\ Higashi-Hiroshima 739-8530, Japan \\ 4 Centre for Renewable Energy and Storage, Suresh Gyan Vihar University, Jaipur 302017, India \\ * Correspondence: shivaniphy@gmail.com (S.A.); ankur.j.ankur@gmail.com (A.J.)
}

check for

updates

Citation: Sharma, S.; Agarwal, S.; Jain, A. Significance of Hydrogen as Economic and Environmentally Friendly Fuel. Energies 2021, 14, 7389 https://doi.org/10.3390/en14217389

Academic Editor: Adam Smoliński

Received: 16 September 2021

Accepted: 2 November 2021

Published: 5 November 2021

Publisher's Note: MDPI stays neutral with regard to jurisdictional claims in published maps and institutional affiliations.

Copyright: (c) 2021 by the authors. Licensee MDPI, Basel, Switzerland. This article is an open access article distributed under the terms and conditions of the Creative Commons Attribution (CC BY) license (https:// creativecommons.org/licenses/by/ $4.0 /)$.

\begin{abstract}
The major demand of energy in today's world is fulfilled by the fossil fuels which are not renewable in nature and can no longer be used once exhausted. In the beginning of the 21st century, the limitation of the fossil fuels, continually growing energy demand, and growing impact of green-house gas emissions on the environment were identified as the major challenges with current energy infrastructure all over the world. The energy obtained from fossil fuel is cheap due to its established infrastructure; however, these possess serious issues, as mentioned above, and cause bad environmental impact. Therefore, renewable energy resources are looked to as contenders which may fulfil most energy requirements. Among them, hydrogen is considered as the most environmentally friendly fuel. Hydrogen is clean, sustainable fuel and it has promise as a future energy carrier. It also has the ability to substitute the present energy infrastructure which is based on fossil fuel. This is seen and projected as a solution for the above-mentioned problems including rise in global temperature and environmental degradation. Environmental and economic aspects are the important factors to be considered to establish hydrogen infrastructure. This article describes the various aspects of hydrogen including production, storage, and applications with a focus on fuel cell based electric vehicles. Their environmental as well as economic aspects are also discussed herein.
\end{abstract}

Keywords: hydrogen energy; hydrogen production; sustainable fuel; environment; energy carrier

\section{Present Energy Infrastructure and Its Problems: Economic and Environmental Point of View}

Energy is one of the fundamental necessities of daily life, without which the structure and standards of society would be affected. The demand of energy refers to the total amount of used energy including electricity and fuels. The energy demand across the world is continuously increasing with the increase in population and economic growth. During the 20th century, the human population has increased six times, whereas the energy consumption has increased by 80 times [1,2]. The efficiency of the energy sources is the main factor affected by resource technology. If there is an improvement in resource technology, it will enhance the efficiency of resources which ultimately increases the total consumption of that resource in two ways: the increment in energy efficiency makes the energy cheaper, and it increases the economic growth.

In ancient times, until the 18th century, energy was being used in the form of fire, muscle power from animals, and steam engines powered by wood fires and by coal. This was followed by the use of oil as it was easy to store, ship, and burn. In the present situation almost $80 \%$ of total energy supply and almost $65 \%$ of electricity production depends upon fossil fuels (coal, oil, and natural gas), as shown in Figure 1 [3]. However, fossil fuel-based energy infrastructure has several environmental and economic aspects which are as follows. 


\section{Fossil Fuels Dominate the World's Energy Complex}

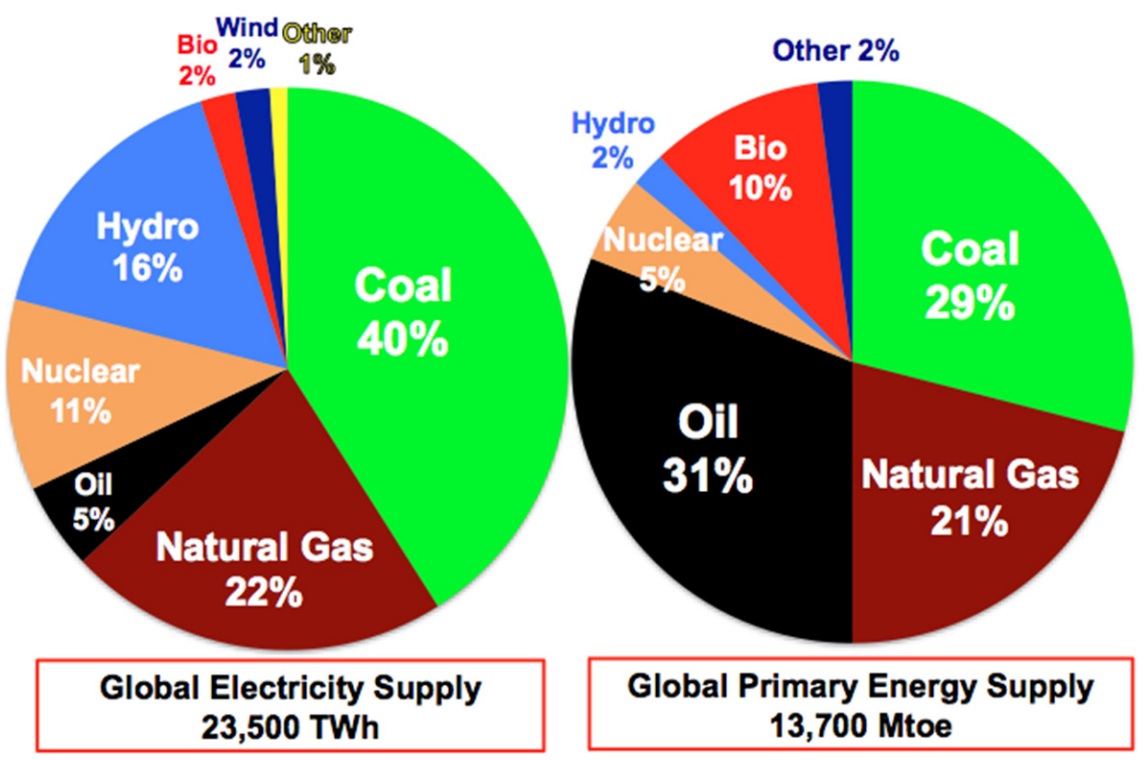

Figure 1. Fossil fuels dominate world's energy system, reproduced from ref. [3] with the permission of Elsevier.

\subsection{Environmental Impact}

There are several problems associated with current energy infrastructure (fossil fuelbased energy system) from an environmental point of view, such as the emission of $\mathrm{CO}_{2}$ and greenhouse gases, air pollution, global warming from burning of fossil fuels, exhaustible and depleting energy sources, acid rains, and degradation of the environment. As the population increases, energy requirements will also increase in the near future. This will increase our dependency on fossil fuels further, which are non-renewable in nature and available for a finite time. Moreover, these fossil fuels including natural gas, coal, and oil which, when burnt, release $\mathrm{CO}_{2}$ and other greenhouse gases and cause air pollution and degrade the environment. Global warming may cause an increase in the global temperature by $1.4-5.8^{\circ} \mathrm{C}$ in the time span from 1990 to 2100 . This will have results such as rises in sea levels, droughts, floods, and heat waves. Hence, excess use of fossil fuels causes the environmental degradation. Figure 2 suggests that greenhouse gases emissions have been continuously increasing through the use of different fossil fuels since 1970 [4]. According to IEA (International Energy Agency) 2019 report, the demand of oil, natural gas, and coal increased to almost 1.4 million barrels/day, 196 billion cubic meters, and 1.4\% respectively. For this fossil fuel-based consumption, USA, India, and China are the primary consumers, and a $2 \%$ annual growth of world $\mathrm{CO}_{2}$ emission was recorded, with almost 33,890.8 million tons, in 2018. During a period of seven years, the rate of carbon emission has increased drastically [5]. The BPSTATS 2019 report mentioned that carbon emissions are directly proportional to the rate of increase in energy consumption [6]. In 2018, almost 13-14\% growth in renewable energy consumption was observed. The foremost reason behind this is the growth in the generation of electricity which is $8-9 \%$ of the total amount. Some countries, for example, China, have already taken numerous initiatives in renewable energy production with 32 Mtoe. In the power sector, renewable energy has been used which constitutes $15 \%$ of its total growth. However, in the power sector, coal is still a significant component which contributes $38 \%$ of its total growth [7].

Due to this serious problem associated with conventional fuels, we need to switch to a new infrastructure which is carbon free and can be considered under sustainable development. The current energy needs must be met without negotiating quality of life through sustainable development. To achieve sustainable development there are many factors to be considered, of which the search of clean energy resource is a primary 
requisite [8-10]. In this connection, the relation between renewable energy sources and sustainable development arises. If we want to attain a clean and sustainable future with minimum environmental problems, these problems associated with conventional fuels must be taken into consideration and we should move towards the adoption of renewable energies, which can be used repeatedly. Thus, there is a continuous search to find alternate fuels which solve this shortage and the problem of environmental degradation. Especially, the problem of environmental degradation draws attraction to clean energy sources, for example, solar energy, wind energy, ocean energy, geothermal energy, and hydrogen energy.

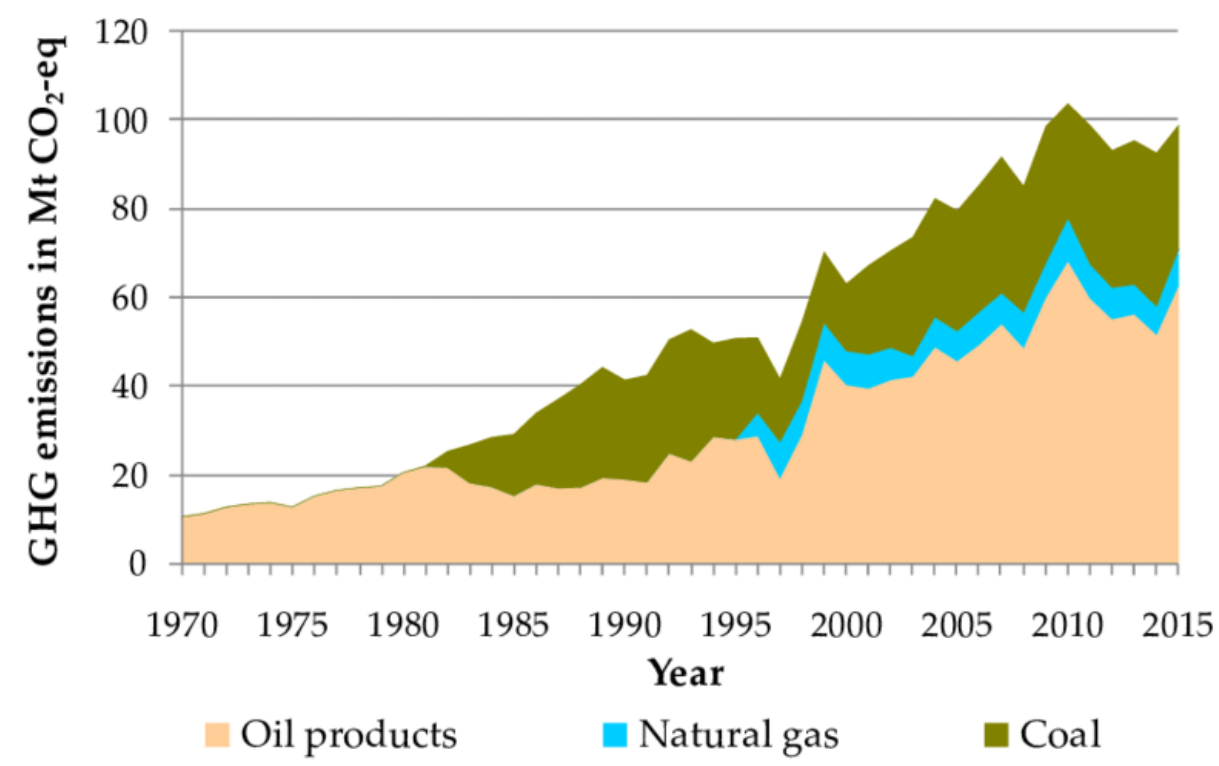

Figure 2. Greenhouse gases emissions by fossil fuels, reproduced from ref. [4] with the permission of MDPI.

\subsection{Economic Feasibility}

The demand for fossil fuels has had a large impact on the economic growth of the country, the standard of living, and the development of society. The total amount of growth of national product depends upon the mean amount of energy expended per capita. The economic growth of the world depends on the energy consumption and availability of fossil fuels. Therefore, a problem arises because fossil fuels are limited on the earth, and are clustered at some particular locations. The non-uniform distribution of these sources creates a lot of burden on the economy of those countries which do not have the natural reserves of these conventional fuels. Several other factors also affect the price of these fossil fuels and so the day-by-day increasing price of oil is creating an energy crisis worldwide. Future economic feasibility of energy must face challenges such as limited resources, energy demand, and climate change [11].

Thus, current energy infrastructure has two main serious issues, which should be addressed urgently. The adoption of renewable energy could be a solution for environmental and economic issues of conventional fuels, as described in detail in next section.

\section{Renewable Energy as a Solution of Problems Associated with Conventional Energy Sources}

As discussed above, in the present era, almost $80 \%$ of global energy demand can be fulfilled by fossil fuels, and the remaining $20 \%$ is achieved from the other sources such as renewable energy. As we have discussed, combustion of fossil fuels causes environmental degradation and several global problems. These global problems can only be solved by the replacement of present energy infrastructure with a renewable energy system which can provide a pollution free solution. This type of transition is inspired by many aspects such as environmental impacts, economic aspects, and limitations on supply of fossil fuels. 
Research into the uses of renewable energy sources began around the 1980s. The energy demand graph [12] for the last 200 years is shown in Figure 3, which describes growing energy demand with time. The growing energy demand in recent decades has forced us to shift towards the increased usage of renewable energy. Since renewable energy sources are dependent on time, weather, and geographical locations, several challenges arise with the increasing use of renewable energy, such as renewable energy resources requiring large areas, being costlier than other energy sources, and the necessity to store the energy that is received from renewable sources. Hence, in recent decades, many techniques have been applied for improving energy efficiency and storage to achieve energy sustainability [13].

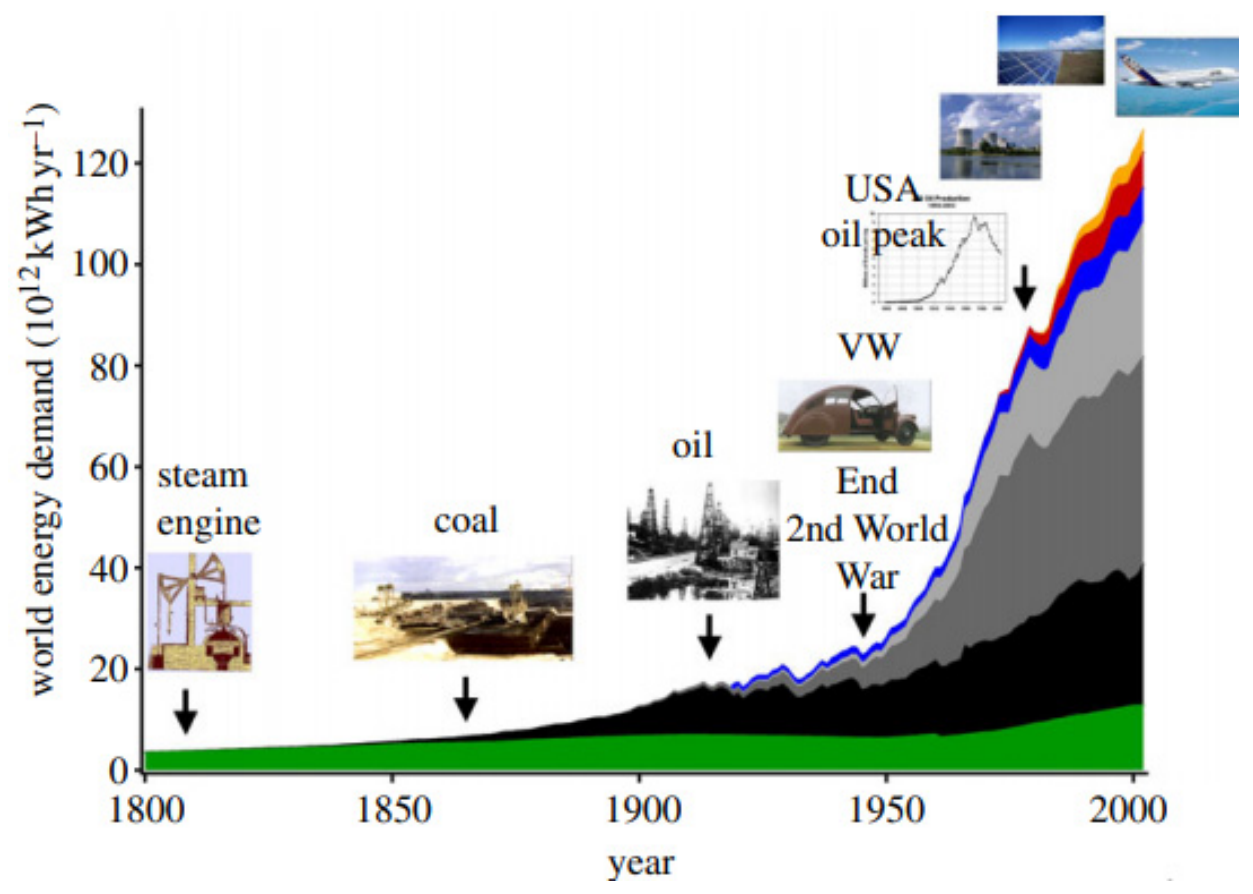

Figure 3. Energy demand over the last 200 years; refer: Green—biomass; black—coal; dark greycrude oil; grey—natural gas; blue-hydro power; red—nuclear fission; Orange-renewables. Reproduced from ref. [12] with the permission of the Royal Society of London.

Non-conventional energy sources such as solar energy, wind energy, ocean energy, geothermal energy, and hydrogen energy are unlimited on the earth and can be directly extracted from natural resources. However, availability of most of non-conventional energy sources, such as solar energy and wind energy, varies across time, weather, and location. Some geographical areas of the globe are compatible for particular forms of renewable energy, whereas the other locations may be lacking. As an example, the availability of conditions for solar energy is highest in northern Africa, south-western United States, Australia, and South America. Similarly, the best areas for wind energy are the southern tip of South America and Northern Europe. Countries such as the Philippines and Iceland are rich in geothermal energy. Every region of the world has some renewable energy resources, but their cost and availability may vary. Therefore, renewable energy sources are available throughout the globe collectively, i.e., at least one renewable energy source is available in every region of the globe, thus can provide each region/country on this earth with economic independency.

According to an IEA (International Energy Agency) 2017 report, there has been a speedy development for the utilization of renewable energy sources because of the decrement in the cost of wind and solar power. Due to this growth, in the year 2022, the renewable energy generation cost is estimated to increase by almost 33\% [14]. As compared to fossil fuels, electricity produced from renewable energy sources causes almost $90-99 \%$ less greenhouse gases and 70-90\% less pollution. From Figure 4, it can be seen that when 
we move away fossil fuels towards renewable energy sources, the effects of climate changes decrease. The impact on climate change reduces with increasing use of renewable energy. From Figure 4, it is clear that large use of solar energy has a higher impact and lesser effect on climate change than other sources. The lowest impacts are observed for both $€ 50 / t$ and $€ 150 / \mathrm{t}$ scenarios where $99 \%$ productions are from renewable energy sources [15]. A panel of data from 2000 to 2016 from almost 25 developing Asian countries was analyzed through HTR (Hausman Taylor Regression) and robust RE (Random Effect) approach.

Climate Benefits of Renewable Energy

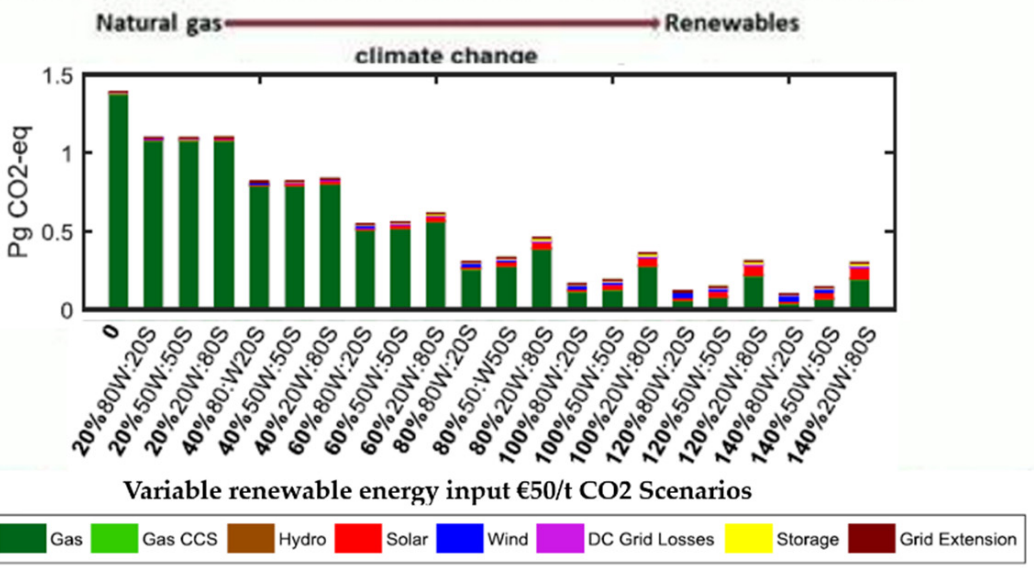

Figure 4. Climate benefits of renewable energy [15].

This study finds a progressive relationship among environmental degradation, energy consumption, and economic growth and suggested that if there is a $1 \%$ rise in the consumption of renewable energy, then carbon emissions can be reduced by almost $0.193 \%$. Thus, this study draws attraction towards the economies of developing Asian countries which have capabilities to save the environment by the use of renewable energy resources and many environmental policies to improve renewable energy infrastructure (RE) and reduce greenhouse gas emissions [5]. Thus, it is clear that renewable energy could be a solution to the environmental and economic issues of conventional fuels. However, the weather, time, and regional dependency of these renewable sources warrant storing them efficiently in secondary energy sources/carriers. For that purpose, among all the available options, hydrogen is considered a promising energy carrier in terms of 3 Es: (i) Environmentally friendly, (ii) Energy Security, and (iii) Economic affordability. In the next section, hydrogen will be introduced as an energy carrier.

\section{Hydrogen as Future Energy Carrier}

As we have discussed earlier, alternative energy resources do not pollute the environment; however, most of them are either time, weather, or location dependent, which forms a gap between the demand and supply of energy. Hydrogen, which can be utilized as an energy carrier and can fill the gap of supply and demand. In renewable energy sources, hydrogen has been proposed as a promising energy carrier, capable of replacing present energy infrastructure [16,17]. It is a "sustainable energy carrier" which is not exhausted by continuous usage, does not contain any environmental issues, pollutants, or cause health issues [18]. Hydrogen is the most abundant and lightest element, available in compound form but not in free form. It can be stored, transported, and can be produced easily from water. As compared to other fuels, it rich in energy per unit mass. It is an energy carrier, not a primary source, which can be produced from other sources like water, biomass, and fossil fuels. As compared to conventional fuels, its gravimetric energy content is 2-to-3-times higher than traditional sources, but it possesses low volumetric energy density [19]. It is useful in, for example, hydrogen powered industries, hydrogen villages, and jet planes. It can generate electricity and is useful for all household energy requirements. By using fuel 
cells, hydrogen can store energy in the form of electricity. Table 1 summarizes the physical properties of $\mathrm{H}_{2}$ [20].

Table 1. Some properties of $\mathrm{H}_{2}$ at ambient conditions [20].

\begin{tabular}{cc}
\hline Atomic number & 1 \\
Atomic mass & $1.00784 \mathrm{amu}$ \\
Molecular mass & $2.01568 \mathrm{amu}$ \\
Energy density & $10.05 \mathrm{MJ} / \mathrm{m}^{3}$ \\
Volumetric density & $0.08376 \mathrm{~kg} / \mathrm{m}^{3}$ \\
Boiling point & $-252.87^{\circ} \mathrm{C}$ \\
Melting point & $-259{ }^{\circ} \mathrm{C}$ \\
Critical point & $-240.2^{\circ} \mathrm{C}$ at $12.7 \mathrm{~atm}$ \\
Triple point & $-259.3^{\circ} \mathrm{C}$ at $0.07 \mathrm{~atm}$ \\
Higher heating value & $141.86 \mathrm{MJ} / \mathrm{kg}$ \\
Lower heating value & $119.93 \mathrm{MJ} / \mathrm{kg}$ \\
\hline
\end{tabular}

Hydrogen has been projected as future energy solution. As an energy source, it has potential to fulfill the energy requirements and to lower $\mathrm{CO}_{2}$ emissions. When burnt in air, fossil fuels emit greenhouse gases, whereas hydrogen produces a clean form of energy with water as a by-product. The comparison of hydrogen and fossil fuels technologies is shown in Figure 5. Using hydrogen produced from conventional methods can reduce the carbon emission by almost $20 \%$ when used in fuel cells. A significant reduction in carbon emission, i.e., a zero-emission level can be achieved by producing hydrogen using renewable sources of energy [21]. Thus, hydrogen can be a clean energy carrier if the technologies associated with it are clean. The current technologies associated with hydrogen production and other aspects are conventional ones, and thus, hydrogen cannot be claimed as a completely clean fuel.

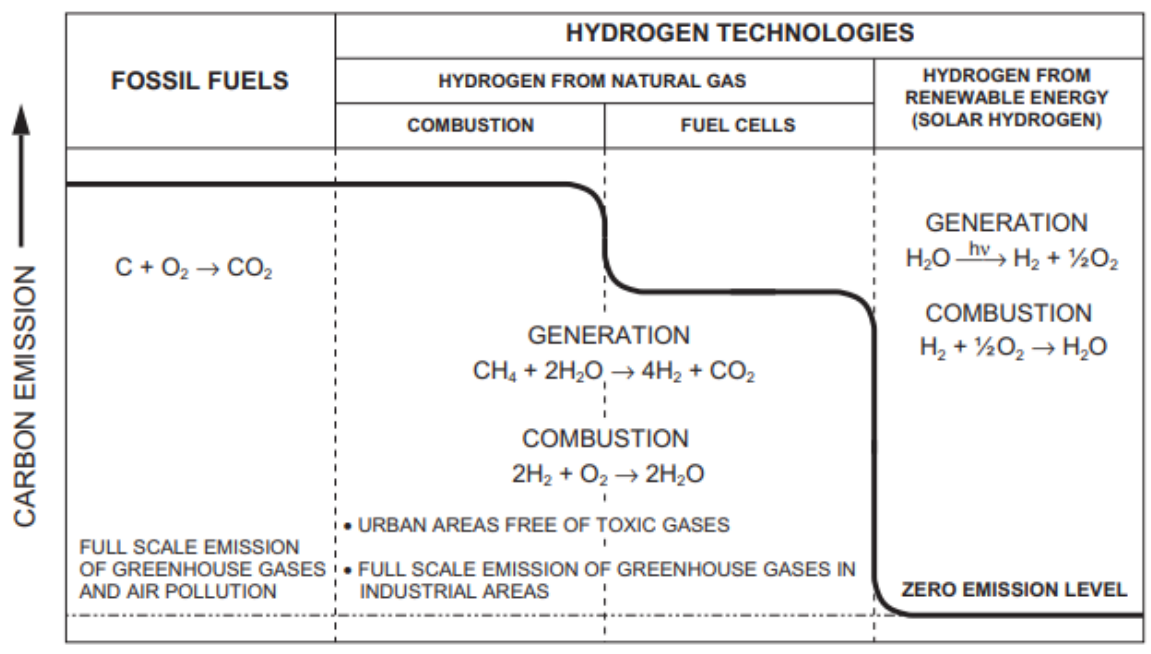

Figure 5. Comparison of fossil fuels and hydrogen combustion on carbon emission. Reproduced from ref. [21] with permission of Elsevier.

There are several reasons for making hydrogen a prominent contender as a replacement option for the fossil fuels. The foremost reason is its environment friendliness, which means that the exploitation of hydrogen does not employ any environmental impact because it produces only water as a product when burnt in air. It is easily transportable. It can be transported over long distances by means of pipeline and can be transported through transmission lines in the form of electricity. The other reason is its recyclability; it oxidizes to water and splits it into its constituent to generate hydrogen. Another reason is related to its reasonable cost with respect to its energy density. In different regions, the cost of $\mathrm{H}_{2}$ varies broadly in the range of 0.8 to $4 \mathrm{USD} / \mathrm{kg}$ depending upon technology and raw 
material costs [22]. The Hydrogen Council 2020 stated that, in the year 2020, $\mathrm{H}_{2}$ energy was used significantly, and it has the potential to solve almost $8 \%$ of GED (global energy demand) and the production cost is around $2.50 \mathrm{USD} / \mathrm{kg}$. By the year 2030, the cost of $\mathrm{H}_{2}$ production is predicted to decrease to around $1.80 \mathrm{USD} / \mathrm{kg}$ and to solve the problem of global energy demand by around 15\%. The Hydrogen Council stated that the demand and supply of $\mathrm{H}_{2}$ will be $10 \mathrm{EJ}$ per year by the end of the year 2050, and afterwards, demand will increase about $5-10 \%$ every year. In addition, $\mathrm{H}_{2}$ would be able to fulfill $18 \%$ of global energy demand in the year 2050. Thus, it is clear that in future, $\mathrm{H}_{2}$ will become an attractive contender in the energy system, because of its low production cost, energy density, and low carbon emission [23].

The next reason is associated with the wide variety of storage options: hydrogen can be stored in different ways (although there are several issues associated with its efficient storage in the present scenario, these can be tailored to improve storage media in the near future). In addition, it can be produced in a clean way: it can be produced from water which is abundant in nature. Its utility in several industries as a chemical fuel is another advantage. In conclusion, if compared with fossil fuels, hydrogen has several advantages so can be seen as an energy fuel in the future [24]. International Energy Agency (IEA) stated that green hydrogen could reduce carbon emissions, but only if the foremost challenges, such as the cost of manufacturing methods, infrastructure, and safety, are overcome. When hydrogen is produced by conventional methods, it is responsible for worldwide $\mathrm{CO}_{2}$ emissions, i.e. about 843 metric tonnes per annum, which is equivalent to the total emissions of the UK and Indonesia together. Globally, demand of hydrogen is anticipated to increase from 70 to 120 million tonnes in the period of 2019 to 2024 . In this regard, the development of hydrogen should be able to satisfy the seventh goal of the United Nations, i.e., "clean and affordable energy" $[25,26]$. Hence, it is predicted that in the year 2025, the biggest worldwide green hydrogen plant will be manufactured whose capacity is of 237,250 tonnes per annum by use of electrolysis, and will be able to achieve 4 gigawatts of renewable energy from solar and wind energy [27].

In this review, the various aspects of hydrogen as fuel, associated techniques, and their environmental impacts are discussed.

The utilization of hydrogen for energy needs contains three major steps: (i) production; (ii) storage; and (iii) application through combustion. These three major steps constitute a closed hydrogen cycle, as shown in Figure 6. In this section, each step, with its environmental impact, will be discussed in detail:

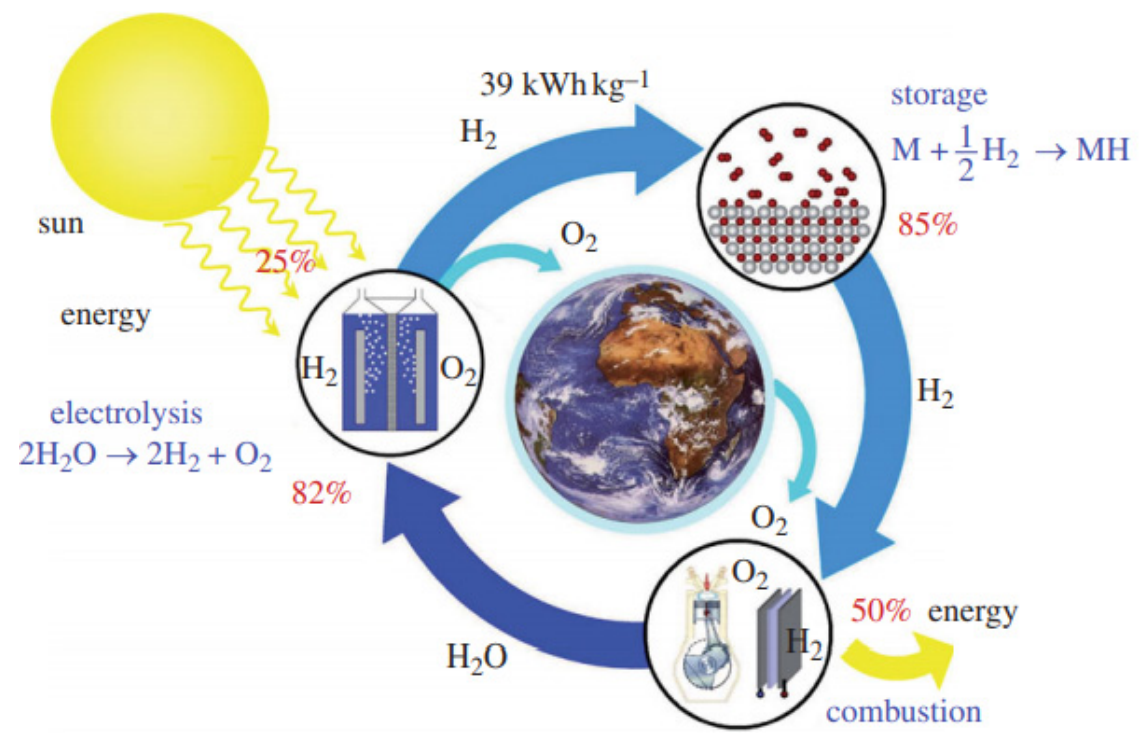

Figure 6. The hydrogen cycle. Reproduced from ref. [12] with permission of the Royal Society of London. 


\subsection{Hydrogen Production}

On the basis of applied energy sources for hydrogen production, there are several methods, such as the conventional fossil fuel method, electrolysis, solar energy method, bio hydrogen production, and thermochemical method. A number of detailed reviews are available on hydrogen production technologies [28-32]. The methods of hydrogen production can be broadly put into two categories: (i) Hydrocarbon based methods and (ii) non-hydrocarbon based methods. The available hydrogen production methods from fossil fuels are steam methane reforming [33-37], partial oxidation of hydrocarbons [38-41], coal gasification [42], biomass gasification [43-49], pyrolysis, etc. In Figure 7, hydrogen productions from different methods are shown [50]. Fossil fuels have been the major feedstocks to produce hydrogen: an estimated $95 \%$ of hydrogen production depends on fossil fuels. However, to maintain the cleanliness of hydrogen fuel, it is necessary to shift from this category to the other category of hydrogen production methods. In the next subsection all the production methods are discussed.

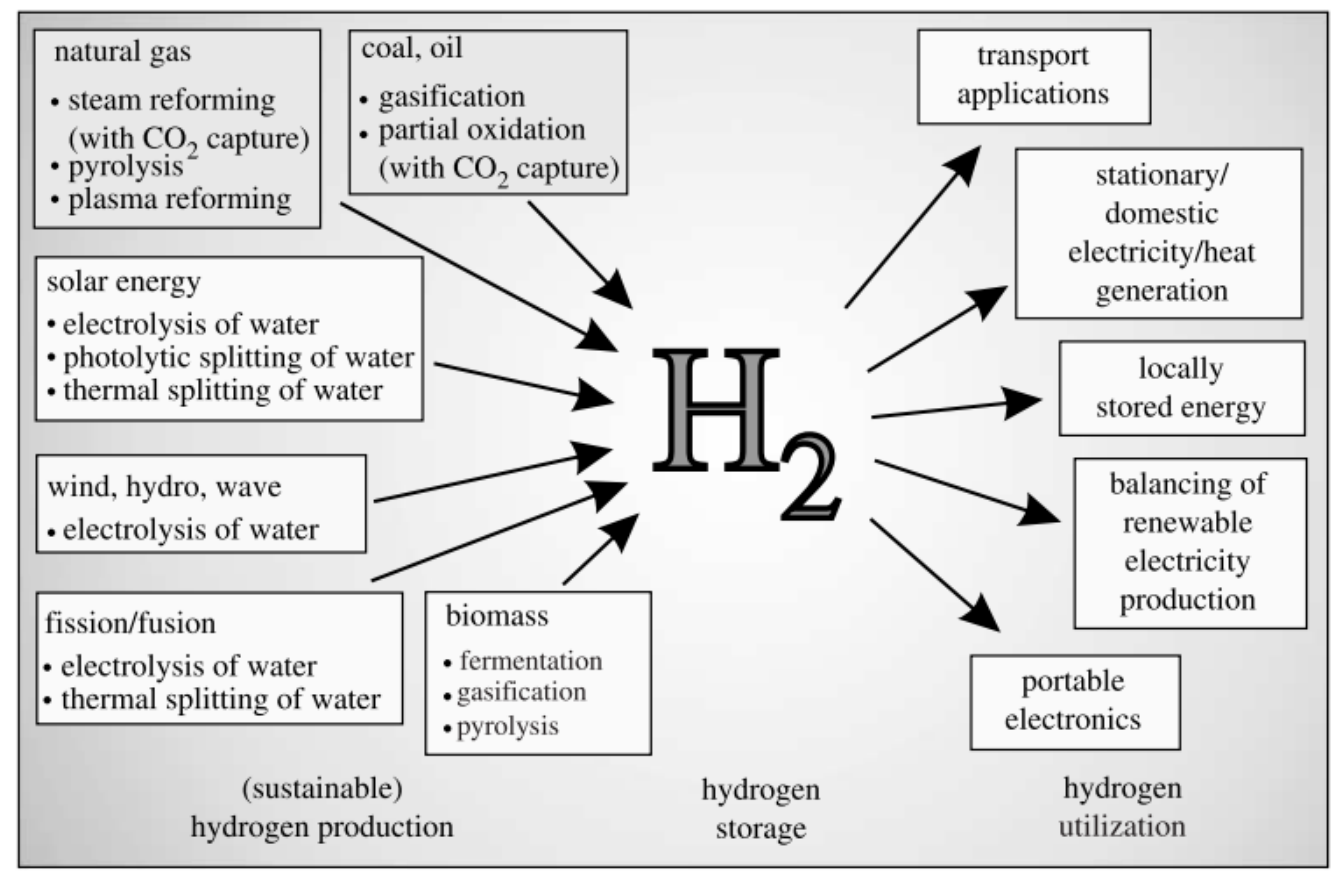

Figure 7. Hydrogen production methods. Reproduced from ref. [50] with permission of the Royal Society of London.

\subsubsection{Hydrogen Production Methods Based on Hydrocarbons}

In the era of fossil fuels, most hydrogen production is from fossil fuels. Steam methane reforming, coal gasification, and partial oxidation of hydrocarbons are the main hydrocarbon-based hydrogen production methods.

The steam reforming method produces a mixture of $\mathrm{CO}$ and hydrogen in the first step. The main steps adopted in this method are reforming, shift conversion, gas purification, and methanation. In this method, the produced hydrogen also contains a small amount of carbon monoxide, hydrogen sulfide, and carbon dioxide as impurities. To remove these impurities, some purification methods have been adopted. This SMR (steam reforming of methane) method has an efficiency in the range of $65-75 \%$.

As several gases are the by-product of this method, it contributes to environmental degradation significantly by the emission of greenhouse gases. The percentage costs of the overall $\mathrm{H}_{2}$ production cost for steam methane reforming (SMR) are $60.7 \%$ feedstock, $29.1 \%$ capital investment, and rest are from others [51]. This shows that corresponding to design capacity, the cost of hydrogen production is $379,387 \mathrm{~kg} /$ day, with a capacity factor 
of almost $90 \%$, and the cost of a natural gas is of $10.00 \$ /$ MMBtu. Regarding this, their carbon capture capacity (with and without) is $2.27 \$ / \mathrm{kg}$ and $2.08 \$ / \mathrm{kg}$, respectively [52].

Another method for hydrogen production is partial oxidation of hydrocarbons, which is adopted generally where heavy oil is available at low cost. However, this method has a lower efficiency of almost $50 \%$. The distribution of hydrogen cost for partial oxidation is $54.6 \%$ capital investment, $25.8 \%$ feedstock, and the rest are from other components [51]. Studies performed for carbon capture with and without hydrogen output showed $276,900 \mathrm{~kg} /$ day and 255,400 kg/day, respectively, and their hydrogen cost as $1.63 \$ / \mathrm{kg}$ and $1.34 \$ / \mathrm{kg}$, respectively [52]. The coal gasification is another prominent technology to produce hydrogen from fossil fuels which have the capacity of producing 97\% pure hydrogen [53-56].

Biomass gasification is the production method, which is very similar to coal gasification; however, biomass has comparatively low calorific value compared to coal, thus it requires a larger plant than coal. These methods are advantageous as they are cheaper and have established techniques for the large scale productions of hydrogen; however, at the same time, all of them generate carbon-based products which makes them unsustainable for a hydrogen economy. The hydrogen production cost of biomass gasification, which depends upon the biomass type and facility size, is assessed to be in the range of $1.25 \$ / \mathrm{kg}$ to $2.20 \$ / \mathrm{kg}$. It is estimated that the hydrogen output is $139,700 \mathrm{~kg} /$ day from biomass, and costs in the range of $1.77-2.05 \$ / \mathrm{kg}[57]$.

To attain the advantages of a sustainable hydrogen energy economy, we must produce hydrogen through non-fossil fuels-based technologies [50].

\subsubsection{Hydrogen Production Methods Based on Non-Hydrocarbons}

Hydrogen production from non-fossil fuels-based methods using water can facilitate solutions to environmental problems, thus making hydrogen a clean fuel in a real sense. There are several non-fossil fuels-based methods such as electrolysis, solar energy method, bio hydrogen production, and the thermochemical method, for which efficiency may vary from 70 to $90 \%$ [58,59].

Electrolysis is the hydrogen production method which split water into oxygen and hydrogen through an electric current. It is used to produce hydrogen on a small scale [60] due to its cost. It is an advanced technology with an efficiency of almost $71 \%$ and produces pure hydrogen from water with no emission of any kind of greenhouse gases [61-63]. Electrolysis at high temperature that exploits water into steam is under development [64-67]. In this technique, energy which is essential for electrolysis is delivered in the form of heat rather than electricity, which is expensive. Electrolysis of water is a cost-effective and sustainable option. Electrolyzers can produce almost $380,000 \mathrm{~kg} \mathrm{H}_{2}$ per year with a $53.4 \mathrm{kWh} / \mathrm{kg} \mathrm{H}_{2}$ of energy consumption, and efficiency is almost equal to $73 \%$ [68]. This method of hydrogen production is presently limited to research and development level.

Thermochemical water splitting is a water decomposition method which is used for large-scale hydrogen production [69-71]. Its inefficiency is due to the conversion of heat to electricity which can be sorted out through thermochemical cycles. The advantage of this method is that it allows water to be decomposed at low temperatures $\left(850-1000{ }^{\circ} \mathrm{C}\right)$. Numerous hydrogen production methods centered on the thermochemical method have been anticipated [72-74]. The interest in thermochemical water-splitting cycles was developed in the 1970s and most of the cycles were projected with a primary nuclear energy source. Hydrogen can be produced through thermochemical water splitting cycles by using nuclear reactors. These cycles require temperatures of $500{ }^{\circ} \mathrm{C}$, or even more, which can be achieved by light-water reactors. The operating temperature of the reactor is an important aspect because high temperatures allow fast reactions and also have greater efficiencies. These thermochemical water splitting cycles with high temperature ranges have the potential to run appropriate, effective cycles. There are more than 100 thermochemical cycles available which could perform reaction of splitting of water in high-temperature reactors. Among the most promising high-temperature cycles are sulfur-iodine or S-I 
cycle and calcium bromide-iron oxide cycles. Besides high-temperature cycles, $\mathrm{Cu}-\mathrm{Cl}$ or copper-chlorine cycle is a significant lower-temperature cycle which could produce hydrogen by heat from a current [74]. This $\mathrm{Cu}-\mathrm{Cl}$ cycle has an efficiency of almost $40 \%$ at a $550{ }^{\circ} \mathrm{C}$ operating temperature. Figure 8 shows hydrogen production from a 5 -step copper-chlorine thermochemical cycle. These types of thermochemical cycle are economically useful for lifetimes [75]. Hydrogen production cost for S-I cycle and $\mathrm{Cu}-\mathrm{Cl}$ cycle is estimated to be $2.63 \$ / \mathrm{kg}$ and $2.17 \$ / \mathrm{kg}$, respectively, and the production rate is 800,000 and $7000 \mathrm{~kg}$ per day, respectively [76].

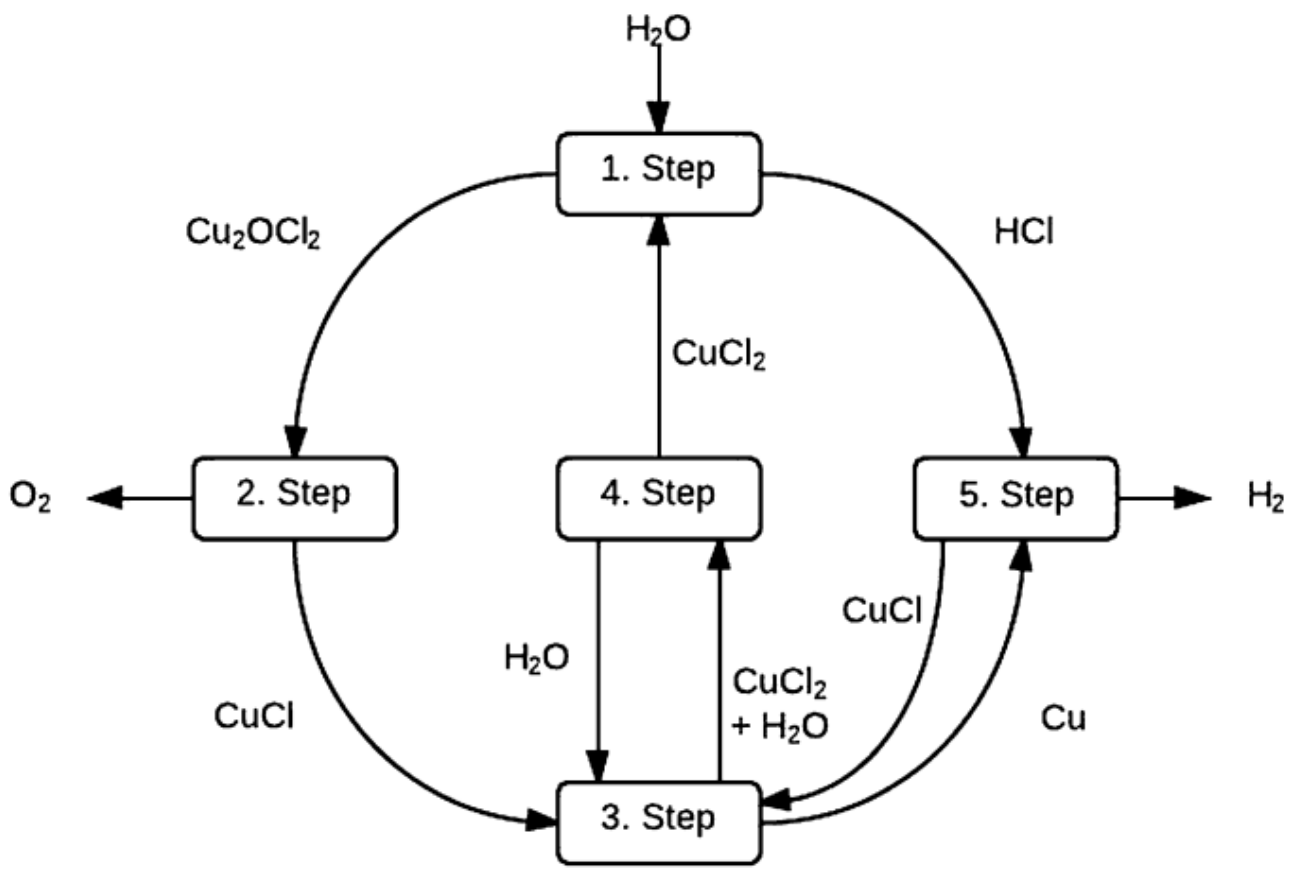

Figure 8. $\mathrm{Cu}-\mathrm{Cl}$ thermochemical cycle for hydrogen production. Reproduced from ref. [74] with permission of Springer Nature.

In the solar energy method, the photoelectrochemical water splitting method is adopted in which solar energy can be converted into electricity within a cell and the generated electricity used for electrolysis. In this method, solar radiations incident on semiconductors and act as a photocatalysts [77]. The expansion of photocatalysts accomplished a wide range of visible light to achieve high hydrogen production [78]. Hence, this method can be used for large-scale hydrogen production and, according to the prediction, almost 10000 photoelectrochemical (PEC) plants will be required by the end of year 2050, which will satisfy one third of the world's energy demand [79]. In the U.S. in the years of 2013 to 2014 , the costs for photovoltaic installations were around $\$ 2.3 \mathrm{~W}_{\mathrm{p}}{ }^{-1}$, and only China and some countries in Europe had lower costs at around $\$ 1.6 \mathrm{~W}_{\mathrm{p}}^{-1}$ and $\$ 1.9 \mathrm{~W}_{\mathrm{p}}{ }^{-1}$ respectively. These cost differences had a higher capacity in the U.S., which suggest location dependent cost differences [57].

Similarly, the bio-hydrogen production method uses biofuel as a source of energy, where microorganisms are used for the hydrogen production by the fermentation and photolysis method. Fermentation can take place as photo fermentation (in the presence of light) and dark fermentation (in the absence of light) through bacteria. Bio-photolysis involves direct and indirect photolysis through microalgae and cyan bacteria. This method is a promising method for commercial production of hydrogen with minimal substrates in future, with high energy density and zero emission of carbon dioxide. The cost of hydrogen is projected to be $2.13 \$$ per $\mathrm{kg}$ of $\mathrm{H}_{2}$ produced. Thus, an increment of around $20 \%$ in the cost suggests $33.33 \%$ higher cost of production. Hydrogen production cost by dark and photo-fermentation is expected to be $2.57 \$ / \mathrm{kg}$ and $2.83 \$ / \mathrm{kg}$, respectively [32]. 
Nowadays, nuclear fission technique is used widely for hydrogen production. For this purpose, nuclear reactors are established which perform water electrolysis at hightemperature ranges. This method could have zero carbon dioxide emissions.

However, all of these procedures have several obstacles which limit their applications. Many procedures are still at the development stage. Hence, hydrogen production from renewable energy sources is not currently economically feasible and these need to be accompanied by non-hydrocarbon energy sources [80-83].

\subsubsection{Environmental Aspects of Production Methods}

Hydrogen produced from fossil fuels contributes to the global warming through the direct combustion of fossil fuels, while hydrogen produced from alternative energy sources such as solar hydrogen energy systems and electrolysis provides permanent, clean, pollution free, and environmentally friendly energy due to recyclability of its generation and combustion. For the available hydrogen production methods, if we compare global warming potential (Figure 9), it is clear that hydrogen production from the steam reforming method (based on fossil fuels) has higher global warming potential, i.e., almost 11.9567 per kg of hydrogen, which is followed by hydrogen mercury cell, hydrogen diaphragm cell, and membrane cell with global warming potentials of 1.0510, 0.9090, and 0.8872 per $\mathrm{kg}$ of hydrogen, respectively. The value is quite low for hydrogen production from electrolysis (non-fossil fuel-based), i.e., 0.0325 per $\mathrm{kg}$ of hydrogen, as compared to hydrogen production from alternative energy sources. The highest value of global warming potential for the steam methane reforming method is associated with the raw material used in this method. The utilization of methane directly causes the emission of greenhouse gases. The lower value of global warming potential for other methods is more related with preutilization methods but not due to the raw material or the direct utilization process. These may include manufacturing and distribution of components required for these methods. As an example, a hydrogen mercury cell provides an excellent way to produce hydrogen; however, the use of mercury itself is undesirable due to its high toxicity and adverse effects if leaked into the environment. The other methods, such as hydrogen via hydrolysis using photovoltaic and wind turbines, give rise the global warming potential due to the fabrication process of turbines or photovoltaic cells, thus possess very low value. Global warming potential is an important factors to understand the adverse effects upon human health and the associated discharge of greenhouse gases [84]. Synthetic fossil fuel and solar hydrogen systems are the foremost replacements to the currently established fossil fuel energy systems; however, they are not comparable from an environmental point of view. Although synthetic fossil fuels are appropriate methods of production, nevertheless they provide more pollution as compared to fossil fuels. In contrast, solar hydrogen energy systems propose a clean, everlasting energy system that is environmentally companionable. So, considering these three energy systems from an environmental point of view, factors such as vapor generation, pollution, and environmental degradation are very much reduced for solar energy systems as compared to the others, which are summarized in Table 2. In this table, the drawbacks of synthetic fuel and the benefits of the solar hydrogen system are visible. The emission of pollutants such as $\mathrm{CO}_{2}, \mathrm{CO}, \mathrm{SO}_{2}, \mathrm{NO}_{\mathrm{x}}$, and $\mathrm{HC}$ are very high for fossil fuels-based energy system, while these are quite low, i.e., almost $0 \%$ for a solar hydrogen energy system. Since the amount of pollutants are quite high in a fossil fuel-based systems, they cause several climate issues such as acid rain and ozone layer depletion. This can be understood from the environmental damage ratio which is much higher (approx. 18 and 23) for fossil fuels and synthetic fuels as mentioned in Table 2. This ratio is negligible for solar hydrogen energy systems due to the absence of carbon, sulfur, or nitrogen-based components.

The emission of $\mathrm{CO}_{2}$ caused the globe's surface temperature to rise of by almost $0.6^{\circ} \mathrm{C}$ during the 20th century. If the emission of $\mathrm{CO}_{2}$ is not reduced, the surface temperature of Earth is expected to increase by 1.4 to $5.8^{\circ} \mathrm{C}$ by the end of the 21st century, leading to a rise in sea levels by $0.5 \mathrm{~m}$. Thus, for slowing down the process, there is an immediate need to 
reduce the emission of greenhouse gases by $60-80 \%$, which is only possible by substituting the energy system to carbon free energy.

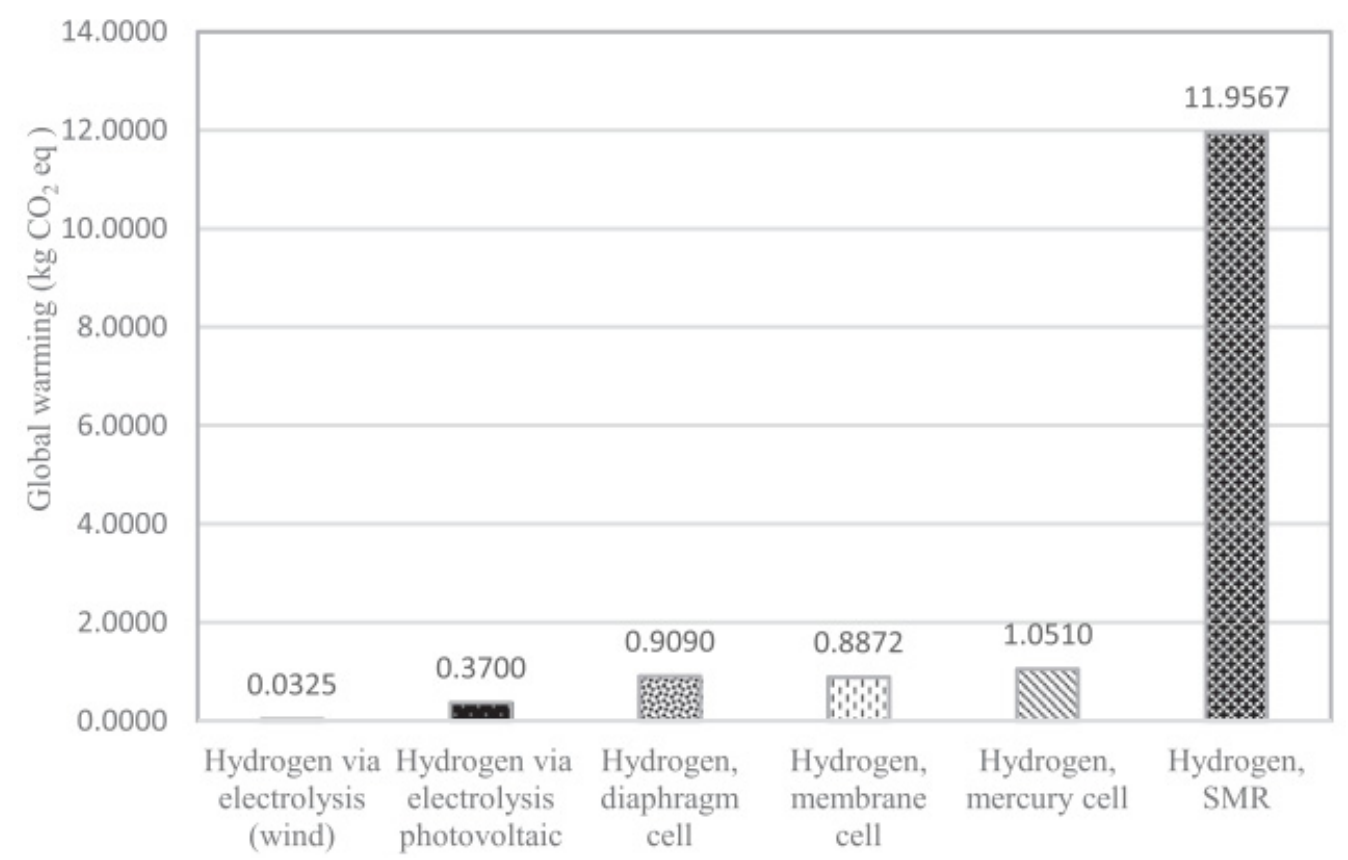

Figure 9. Global warming potential for different hydrogen production methods. Reproduced from ref. [84] with permission of Elsevier.

Table 2. Environment related properties of the main energy systems. Reproduced from ref. [85] with permission of Elsevier.

\begin{tabular}{|c|c|c|c|c|c|c|c|c|c|c|c|}
\hline \multirow[b]{2}{*}{ Energy System } & \multicolumn{6}{|c|}{ Pollutants (kg/GJ) } & \multicolumn{3}{|c|}{ Vapour Generation } & \multirow{2}{*}{$\begin{array}{l}\text { Environmental } \\
\text { Damage Ratio }^{c}\end{array}$} & \multirow{2}{*}{$\begin{array}{c}\text { Environmental } \\
\text { Compatibility } \\
\text { Factor }\end{array}$} \\
\hline & $\mathrm{CO}_{2}$ & $\mathrm{CO}$ & $\mathrm{SO}_{2}$ & $\mathrm{NO}_{x}$ & $\mathrm{HC}$ & $\mathbf{P M}^{\mathbf{a}}$ & $\begin{array}{l}\text { Energy } \\
\text { System }\end{array}$ & $\begin{array}{c}\text { Global } \\
\text { Warming }\end{array}$ & $(\%)^{b}$ & & \\
\hline Fossil fuel & 72.40 & 0.80 & 0.38 & 0.34 & 0.20 & 0.09 & 8.9 & 3900 & 0.782 & 18.24 & 0.055 \\
\hline $\begin{array}{l}\text { Coal/Synthetic } \\
\text { fossil fuel }\end{array}$ & 100 & 0.65 & 0.50 & 0.32 & 0.12 & 0.14 & 9.3 & 3900 & 0.782 & 22.62 & 0.044 \\
\hline $\begin{array}{l}\text { Solar-hydrogen } \\
\text { Energy }\end{array}$ & 0.00 & 0.00 & 0.00 & 0.00 & 0.10 & 0.00 & 6.0 & 0.0 & 0.001 & 1.0 & 1.00 \\
\hline
\end{tabular}

${ }^{a}$ Particulate matter. ${ }^{b}$ With respect to annual vapor generation due to solar heating $\left(5 \times 10^{17} \mathrm{~kg} / \mathrm{y}\right) .{ }^{\mathrm{c}}$ (Damage due to fuel)/(Damage due to solar hydrogen).

Hydrogen production from thermochemical water splitting cycles is also environmentally friendly in terms of $\mathrm{CO}_{2}$ emission, acid rain, and providing sustainable fuel. This can be summarized in "operational guide to the ISO standards" which was described in 2001 by the CML (Centre of Environmental Science of Leiden University). Figure 10 describes the results based on environmental effects in the form of AP (acidification potential) and GWP (global warming potential) for particular methods of hydrogen production. From the figure, the global warming potential and acidification potential are lowest for hydrogen production through thermochemical cycles while these values are highest for coal [75].

Thus, it can be concluded that as soon as the production of hydrogen is completely based on non-fossil fuel energy systems, it will become a sustainable fuel [85]. Many activities to support and ignite this type of change are going on, such as the first World Climate Conference, held on the subject of climate change in 1979. The main aim of this conference was to draw the attention of the public towards the adverse effects of climate change and to establish that long use of fossil fuels resulted in $\mathrm{CO}_{2}$ accretion in the atmosphere, leading to discrepancies in climate. In June 1992, the UN Framework contract on climate change was the one of the most noteworthy efforts for reducing greenhouse 
gas emissions at a particular level. Thus, these types of activities started the perception of sustainable growth [86].

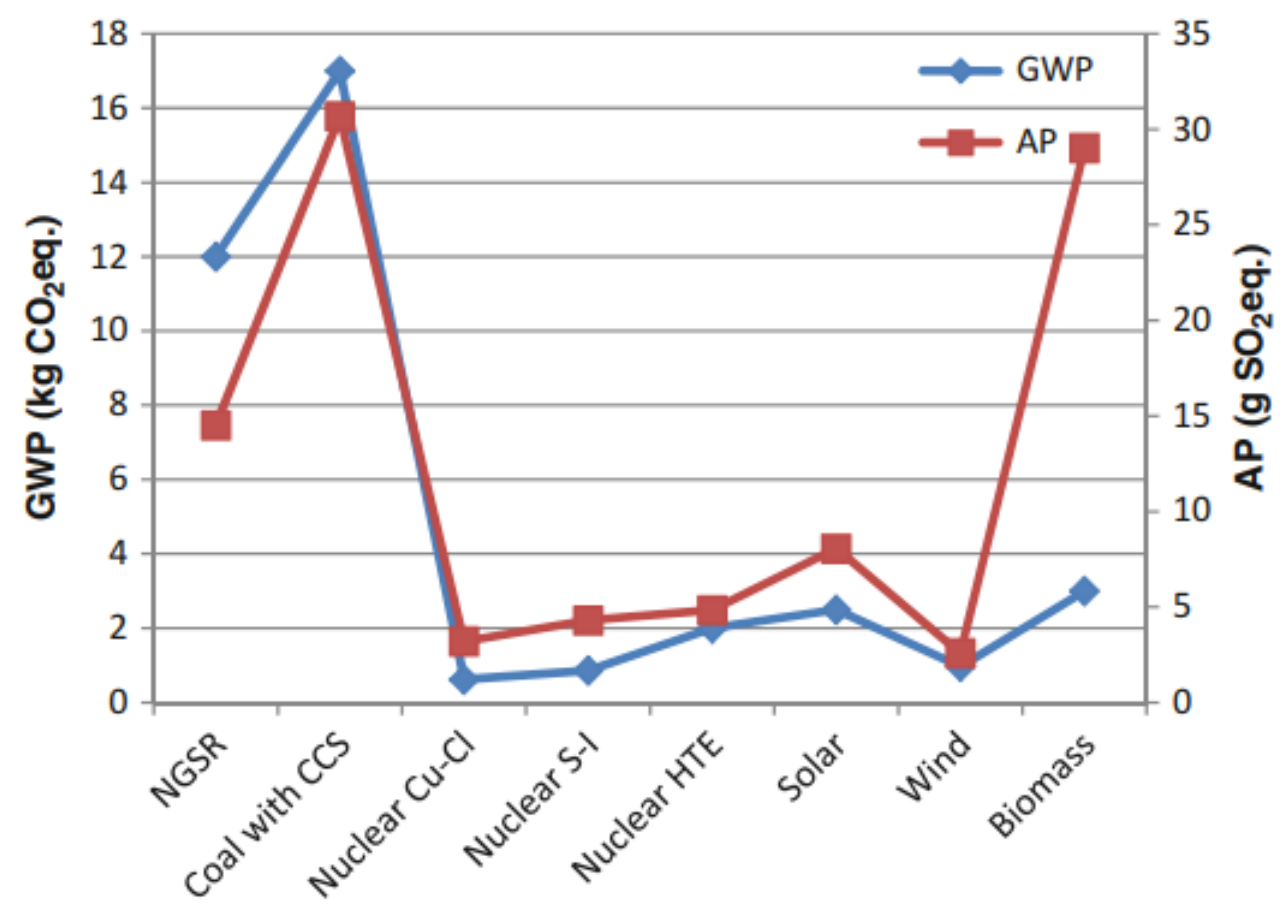

Figure 10. GWP and AP of particular hydrogen production methods. Reproduced from ref. [75] with permission of Springer Nature.

\subsubsection{Economic Aspects of Production Methods}

The economics of hydrogen energy systems can be assessed through the cost of hydrogen storage, production, utilization, and transportation of hydrogen $[87,88]$. Presently, amongst these factors, $\mathrm{H}_{2}$ production is a dominant factor, and is dependent upon the cost of primary sources of energy [61]. Considering the economic aspect, new hydrogen production technologies using renewable energy are presently costly compared to fossil fuels-based hydrogen production methods. The cost of hydrogen production from nonfossil fuel-based sources is influenced by the cost of electricity. The most prominent method for the production of hydrogen from non-fossil fuel sources is electrolysis, but the cost of electrolysis is affected by the cost of the electrolyzer and its utilization. Thus, hydrogen production from electrolysis is cost competitive with other paths of hydrogen production with the absence of $\mathrm{CO}_{2}$, hence provides green electricity. Correspondingly, hydrogen production cost based on fossil fuels depend on their cost. For example, as a comparative point of view, the main obstacles in thermochemical methods are the existence of pressure swing absorption, methods to purify $\mathrm{H}_{2}$, and catalyst cost: all of these factors increases the cost of $\mathrm{H}_{2}$ production; however, it decreases the biomass cost and increases the efficiency [89]. Water electrolysis procedure is a feasible possibility for small-scale hydrogen production from an economics aspect; meanwhile, for large scale production, the cost increases to about $5 \%$ for electrolyzer due to the high use of electricity. The $\mathrm{H}_{2}$ production cost for the dark and photo fermentative methods were expected to be 2.5 to 2.8 USD per kg [57]. In 2017, Sharma and Kaushik stated the cost of $\mathrm{H}_{2}$ production for the dark and photo fermentative methods was around 3.70 and 18.70 USD, respectively [90]. Recently, for Australia, it was stated that for steam methane reforming and for coal gasification production the cost of hydrogen in Australia is around $\$ 1.88$ to $\$ 2.30$ per $\mathrm{kg} \mathrm{H}_{2}$ and $\$ 2.02$ to $\$ 2.47$ per $\mathrm{kg}$ $\mathrm{H}_{2}$, respectively. In electrolysis methods, the costs for alkaline electrolysis and for proton exchange membrane is $\$ 4.78$ to $\$ 5.84 / \mathrm{kg} \mathrm{H}_{2}$ and $\$ 6.08$ to $\$ 7.43 / \mathrm{kg} \mathrm{H}_{2}$, respectively. The production cost for partial methane oxidation via synthesis gas is 1.33 euros $/ \mathrm{kg} \mathrm{H}_{2}$ [27]. In another study, Hay et al. stated that the production of $\mathrm{H}_{2}$ from natural gas and coal 
contain 2.48 to 3.15 USD per $\mathrm{kg}$ and 0.37 to 1.82 USD per $\mathrm{kg}$, respectively. Although, for solar and wind energy, the cost was observed high in the years 2011 to 2016, with the rate growing up to $5.6 \%$ yearly, and established that the $\mathrm{H}_{2}$ market will raise around USD 87.3 to 118 billion in the period from 2011 to 2016 by 6.21\% [91]. Kalamara obtained that SMR is an inexpensive and favorable method for $\mathrm{H}_{2}$ production, with the price of $\mathrm{H}_{2}$ at around 7 USD/GJ, and the price of $\mathrm{H}_{2}$ for pyrolysis and biomass gasification is expected in the range of $8.91-5.51 \$$ per GJ and 10 to $14 \$$ per GJ [92].

In Table 3, the cost of numerous hydrogen production technologies is shown. The cost of steam methane reforming is much lower $(0.75 \$ / \mathrm{kg})$ than the other methods of hydrogen production. Solar electrolysis proposes the highest cost $(5.0 \$ / \mathrm{kg})$ of hydrogen production at the moment; however, with the development of technologies, the cost can be lowered, and it could be the best option in future from an environmental point of view.

Table 3. Costs of hydrogen production technologies. Reproduced from ref. [24] with permission of Springer.

\begin{tabular}{ccc}
\hline Source & Technology & Production Cost (\$/kg) \\
\hline Methane & Steam reforming & 0.75 \\
\hline Coal & Gasification without $\mathrm{CO}_{2}$ sequestration & 0.92 \\
\hline \multirow{2}{*}{ Nuclear } & Electrolysis & $2.6-3.0$ \\
\cline { 2 - 3 } & Water splitting & $1.4-2.3$ \\
\hline Biomass & Centralized biomass gasification & $1.2-2.4$ \\
\hline Solar & Photo catalytic water splitting & 5.0 \\
\hline
\end{tabular}

Therefore, the commercial development of these methods with time, and, according to their negligible environmental impact, the cost of $\mathrm{H}_{2}$ production is anticipated to be less or comparable to that of conventional methods using fossil fuels [86].

\subsection{Hydrogen Storage}

Hydrogen has proved to be an energy carrier instead of energy source, meaning it can deliver and store energy in a useful form [93]. However, being lightweight, its storage is one of the aspects which need serious attention. It can be stored in various ways either in physical or chemical forms. Figure 11 summarize all the methods of hydrogen storage.

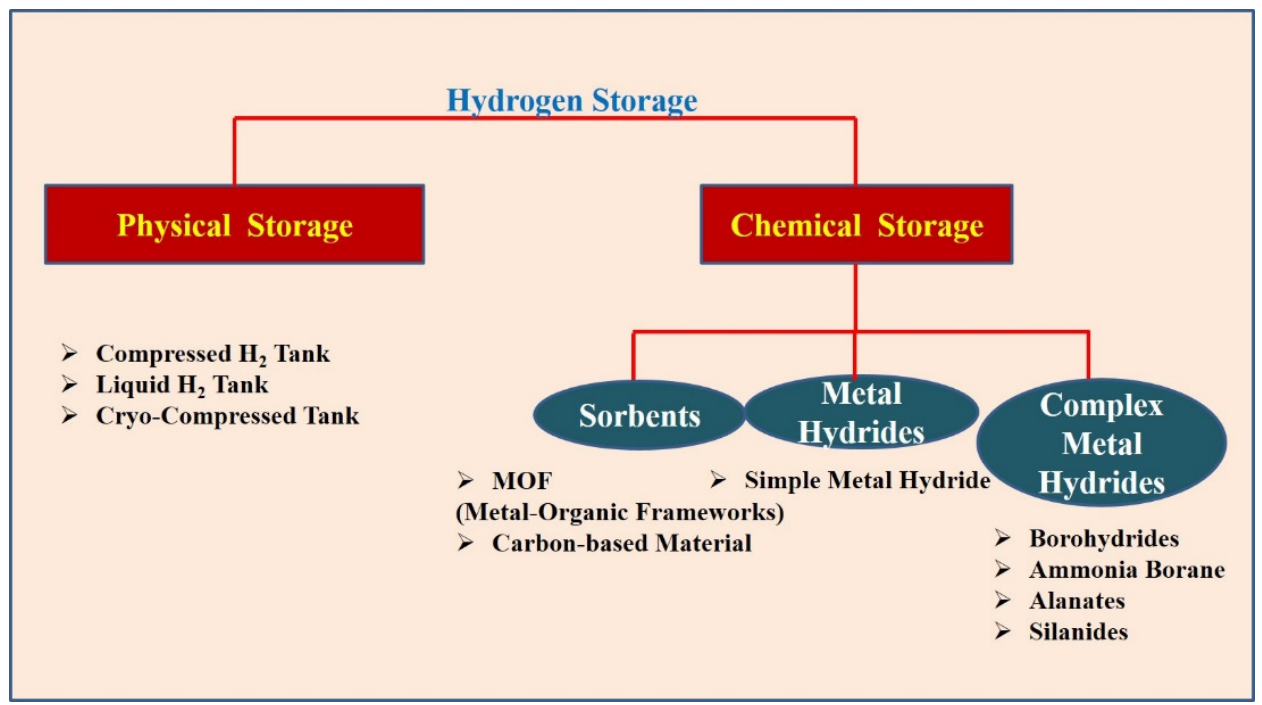

Figure 11. Types of hydrogen storage. 


\subsubsection{Physical Storage}

Physical storage stands for the storage of hydrogen in its molecular form. The options to store hydrogen in molecular form are liquid hydrogen tanks and compressed hydrogen gas tanks. In liquid state, hydrogen needs almost double space as compared to gasoline. Liquid hydrogen can be stored through a process of compression and cooling in cryogenic tanks; the work necessary is predictable to $15.2 \mathrm{kWh} / \mathrm{kg}$, achieving volumetric density is $70.8 \mathrm{~kg} / \mathrm{m}^{3}$, and the gravimetric density is influenced by the tank size. In a compressed state, this amount is increased 3-5 times, with 5000 and 10,000 psi tanks. High pressure gaseous hydrogen storage achieves high pressures of up to $77 \mathrm{MPa}$ by use of pistontype mechanical compressors, and the work required for the compression is more than $2.21 \mathrm{kWh} / \mathrm{kg}$, which delivers a volumetric and gravimetric density of $40 \mathrm{~kg} / \mathrm{m}^{3}$ and $13 \mathrm{wt} \%$, respectively [27]. There are some disadvantages to store hydrogen in liquid form, and a gaseous state requires large physical volume, at high cost, high energy consuming, high pressure, very low temperature, and most importantly safety issues, which make them not feasible for commercial application.

Hence, due to several issues to store hydrogen in liquid and gaseous state, the third method of hydrogen storage in chemical form has attracted the attention of scientists as it decreases the essential pressure of storage and increases the volumetric capacity. A comparison of required space was demonstrated by Edwards et al. [50] and sketched here in Figure 12. Four kilograms of hydrogen needs bulky tanks for its liquid and gaseous states, while as greater amount of hydrogen in chemical form needs far less volume.

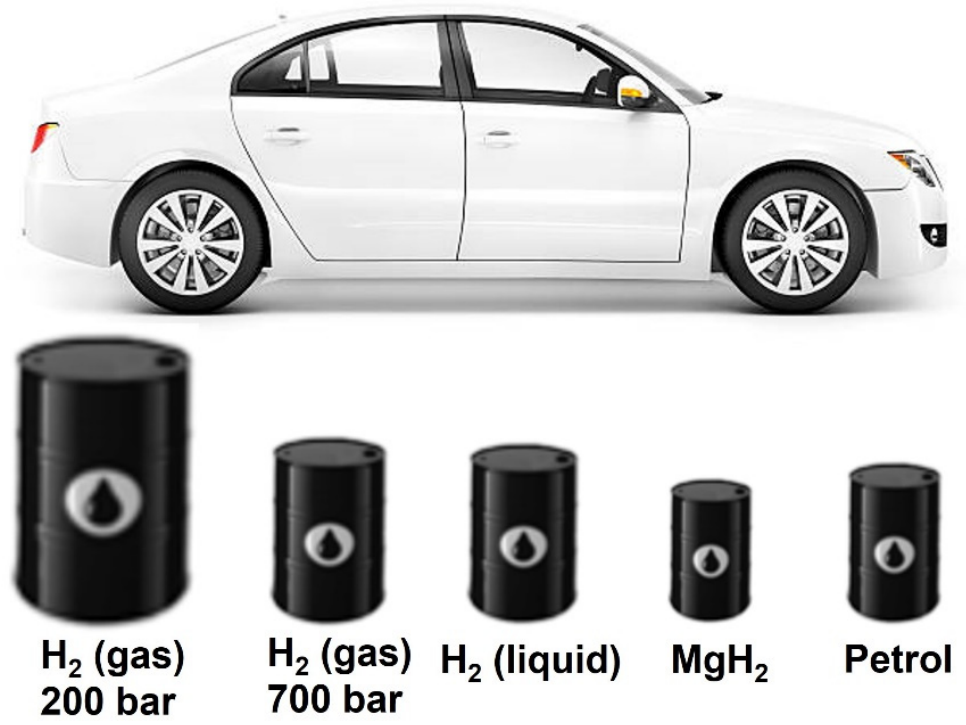

Figure 12. The storage of hydrogen in different ways.

\subsubsection{Chemical Storage}

In the chemical storage method, hydrogen can be stored in solid state materials. In the last few decades solid state materials have been the subject of numerous studies. Several materials have been explored in search of a suitable material which fulfils the requirements as per US-DOE, for example, a storage capacity greater than $8 \mathrm{wt} \%$ and an operating temperature of $40-85{ }^{\circ} \mathrm{C}[94,95]$. There are numerous materials such as sorbents, light metal hydrides, and complex metal hydrides. In sorbent systems hydrogen is connected to the surface through physisorption such as C-based materials and MOFs (Matel Organic Framework). These systems need a very low operating temperature which is not practically possible, and their storage capacity is not so good [96], therefore light metal hydrides and complex metal hydrides are prominent methods as they require comparatively feasible working temperatures and have good hydrogen storage capacity as per US-DOE goals [97]. 
To form light metal hydrides, hydrogen interact with metals through different bonds. These are also categorized in two types: interstitial hydrides, such as $\mathrm{LaNi}_{5}$ and FeTi, which cannot be used commercially for dynamic/onboard needs due to their low hydrogen storage capacity [98], and ionic or covalent hydrides, such as $\mathrm{LiH}$ [99] and $\mathrm{MgH}_{2}$ [100], which are quite suitable for hydrogen storage due to their high hydrogen storage capacity, but which require a very high operating temperature. Many investigations have been done on these materials, but high temperature is still required [101]. In chemical hydrides, hydrogen is connected through covalent bonds with high storage capacity, but these hydrides are irreversible [102,103].

Another sub-class of metal hydrides are complex metal hydrides [104]. Among all the hydrides, complex metal hydrides are the most promising because of their high storage capacity. They also retain two issues. These include thermodynamic and kinetic issues, because of which these materials make stable hydrides and require a high operating temperature: greater than $200{ }^{\circ} \mathrm{C}$. These issues can be solved by downsizing the particles and using catalysts. Thus, solid-state storage is the prominent method to store large amounts of hydrogen at ambient pressure and temperature. Carbon nanotubes (CNT) are able to store $\mathrm{H}_{2}$ at sufficiently low temperatures $\left(196.15^{\circ} \mathrm{C}\right)$ and pressures $(6 \mathrm{MPa})$, and provide a gravimetric density of $10.8 \mathrm{wt} \%$ and volumetric density of $41 \mathrm{~kg} / \mathrm{m}^{3}$ [27]. Nanomaterial offer many advantages in hydrogen storage media which overcome the rate of sorption kinetics, barriers of bulk materials, and release temperature. At the University of South Florida, the clean energy research center's research showed that enhancement in storage capacity and sorption kinetics can be improved through nanomaterials-based catalyst doping. This is because of short diffusion distance in comparison to bulk materials [27].

The comparative study of all these metal hydrides on the basis of storage capacity and operating temperature are summarized in Table 4 [97]. Therefore, continued investigation is taking place on these metal hydrides to explore their properties.

Table 4. Comparative of different solid state hydrogen storage systems. Reproduced from ref. [97].

\begin{tabular}{|c|c|c|}
\hline Hydrogen Storage Materials & $\begin{array}{l}\text { Hydrogen Storage } \\
\text { Capacity }\end{array}$ & $\begin{array}{l}\text { Operating } \\
\text { Temperature }\end{array}$ \\
\hline $\begin{array}{c}\text { Sorbent Systems } \\
\text { Ex.-C-based materials, MOFs }\end{array}$ & $2-7 w t \%$ & $\sim 77 \mathrm{~K}$ \\
\hline $\begin{array}{l}\text { Conventional metal hydrides } \\
\text { Interstitial Hydrides Ex.-- } \mathrm{LaNi}_{5}, \mathrm{FeTi} \text { etc. } \\
\text { Ionic/covalent hydride Ex.-- } \mathrm{LiH}, \mathrm{MgH}_{2} \text { etc. }\end{array}$ & $\begin{array}{l}1 \sim 4 w t^{\%} \\
>7 w t \%\end{array}$ & $\begin{array}{c}\mathrm{RT} \\
>600 \mathrm{~K}\end{array}$ \\
\hline $\begin{array}{l}\text { Chemical Hydrides } \\
\text { Ex.- }-\mathrm{NH}_{3}, \mathrm{NH}_{3} \mathrm{BH}_{3} \text { etc. }\end{array}$ & $17.8 \sim 20 \mathrm{wt} \%$ & $373 \sim>773 \mathrm{~K}$ \\
\hline $\begin{array}{l}\text { Complex Hydrides } \\
\text { Alanates Ex.-- } \mathrm{LiAlH}_{4}, \mathrm{NaAlH}_{4}, \mathrm{Mg}\left(\mathrm{AlH}_{4}\right)_{2} \text { etc. } \\
\text { Borohydrides Ex.- }-\mathrm{LiBH}_{4}, \mathrm{NaBH}_{4}, \mathrm{Mg}\left(\mathrm{BH}_{4}\right)_{2} \text { etc. } \\
\text { Amides Ex.- }-\mathrm{LiNH}_{2}, \mathrm{NaNH}_{2}, \mathrm{Mg}\left(\mathrm{NH}_{2}\right)_{2} \text { etc. } \\
\text { Silanides Ex.- }-\mathrm{KSiH}_{3}, \mathrm{RbSiH}_{3}, \mathrm{CsSiH}_{3}\end{array}$ & $\begin{array}{c}5.8 \sim 10.5 \mathrm{wt} \% \\
10 \sim 18.5 \mathrm{wt} \% \\
5 \sim 10 \mathrm{wt} \% \\
2 \sim 4.5 \mathrm{wt} \%\end{array}$ & $\begin{array}{c}\geq 400 \mathrm{~K} \\
\geq 400 \mathrm{~K} \\
\geq 400 \mathrm{~K} \\
\mathrm{RT} \sim 500 \mathrm{~K}\end{array}$ \\
\hline
\end{tabular}

\subsubsection{Environmental Aspects}

Hydrogen storage is a method used for storing hydrogen for later use. It is one of the fundamental barriers for the wide usage of hydrogen as an energy carrier. The possible storage methods are: Liquid hydrogen storage, compressed hydrogen gas storage, underground hydrogen gas storage, and metal hydride storage. The interest in hydrogen storage is in zero-emissions vehicles, which motivate the growth of new storage methods. Hydrogen storage provides a clean and sustainable form of energy and causes no bad environmental impact. It provides environmentally friendly storage of fuel. 


\subsubsection{Economic Aspects}

The costs of different hydrogen storage methods are given in Figure 13. The fueling cost of 700 bar tanks is much higher $\left(1.94 \$ / \mathrm{kg} \mathrm{H}_{2}\right)$, whereas it is $1.23 \$ / \mathrm{kg} \mathrm{H}_{2}$ for a metal hydride tank; lower than the 700 bar tanks. Thus, by comparing all the hydrogen storage technologies, metal hydride and fuel cell electric vehicle appear to be the most promising techniques of storage as of now [105].

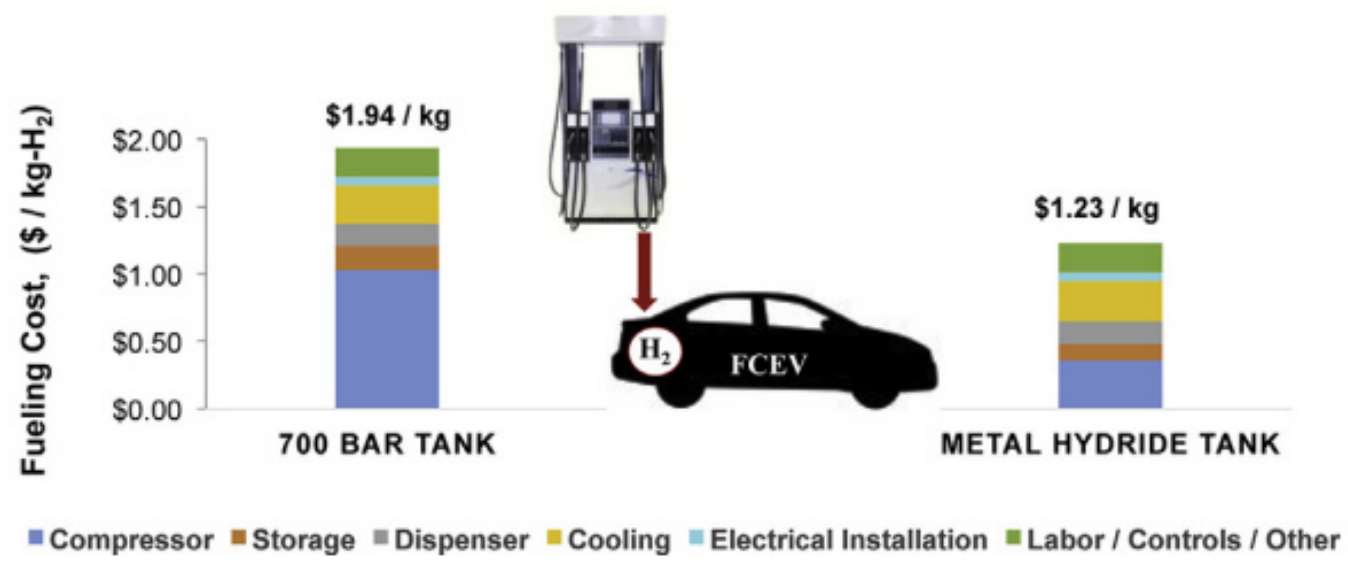

Figure 13. Cost of hydrogen storage methods, Reproduced from ref. [105] with permission of Elsevier.

The costs of hydrogen storage had also been studied by Reus et al., who observed in their study that for compressed gas hydrogen storage, the costs are high, and special maintenance such as low pressures are required for these tanks whose cost is almost $\$ 850$ to store $1 \mathrm{~kg}$ of hydrogen. The cost of Liquid Organic Hydrogen Carriers storage is expected at $50 € / \mathrm{kg} \mathrm{H}_{2}$ which is more cost-effective as compared to cavern storage systems [106]. Hydrogen supply cost with Liquid Organic Hydrogen Carriers (LOHC) is in the range of $8-10 € / \mathrm{kg}$. In another study related to cost, it was specified that for hydrogen production distribution costs were $5 € / \mathrm{kg} \mathrm{H}_{2}$ and in the range of 6.40 to $8.10 € / \mathrm{kg} \mathrm{H}_{2}$ [107]. In another study in 2010, the cost was proposed in the range of $\$ 5$ to 10 per $\mathrm{kg}$ for transport [108]. Hence, we can say that for new studies this cost has decreased. Hydrogen transportation and storage on a large scale is a subject for development, and consequently there are shortages in studies related to costs. In future, new catalysts which will be able to increase the rate of hydrogen sorption kinetics should be researched.

Besides this, to consider economical aspects, two types of hydrogen storage systems need to be considered: (i) Transportation applications and (ii) stationary applications. These applications have different necessities and limitations. The transportation sector will be the most prominent application of hydrogen economy in the near future. The requirements of hydrogen storage for transport applications are harsher than those for stationary applications. The requirements for the transportation sector are as follow: lower operating temperature, low-operating pressure, need of multiple cycle reversibility of hydrogen uptake and release, fast kinetics, high gravimetric and volumetric hydrogen densities, and hydrogen storage cost which is less than $£ 15 / \mathrm{kg}$. Currently, there are no hydrogen storage system available that could satisfy all these conditions. Stationary applications have less constraints for hydrogen storage materials as compared to transportation applications, such as these can be operated at high temperatures and pressures, can occupy a large area, and can have slower kinetics. However, hydrogen storage for stationary use also has many challenges. Compressed gas and liquid hydrogen storage options cannot fulfil most of the conditions described above. The advancements in solid-state hydrogen storage materials would have a drastic impact on hydrogen economy. 


\subsection{Utilization of Hydrogen}

The hydrogen utilization as an energy carrier widely depends upon the accessibility of techniques and its conversion to electricity and heat. Figure 14 shows the utilization of hydrogen in various fields [109]. As discussed earlier, the speedy adoption of hydrogen as an energy carrier all around the world will depend on the conversion of hydrogen into electricity. Fuel cells are emerging as a prominent technology to replace fossil fuelbased energy systems. HFCs (hydrogen fuel cells) release only water and no hazardous contaminant, as is the case with internal combustion engines. Fuel cells have been projected and implemented successfully as the most competent conversion device. A fuel cell is a device which produces electricity by the reaction of oxygen from air and hydrogen, similar to a battery. The difference between a fuel cell and a battery is that batteries store energy, whereas fuel cells produce electricity. The schematic of fuel cell is shown in Figure 15. A fuel cell consists of an anode and cathode which are separated by an electrolyte. Hydrogen is fed into the anode and oxygen into the cathode of the fuel cell, and the reactions take place at these electrodes. The ions transport through the electrolyte among the electrodes and surplus electrons provide electrical current, and flow through an external circuit. If we compare the efficiencies of a petrol driven car and hydrogen fuel cell engines, hydrogen fuel cell leads the race with $65 \%$ efficiency, which is more than double that of petrol engines $(\sim 25 \%)$. The efficiency is further enhanced up to $85 \%$ when a fuel cell is used in CHP (combined heat and power) systems $[110,111]$. This characteristic makes the fuel cell ideal for a range of applications such as vehicle, mobile phone batteries, and power generation. The presence of fuel cells in the automotive market, their infrastructural, environmental, and economic aspects are discussed in this section.

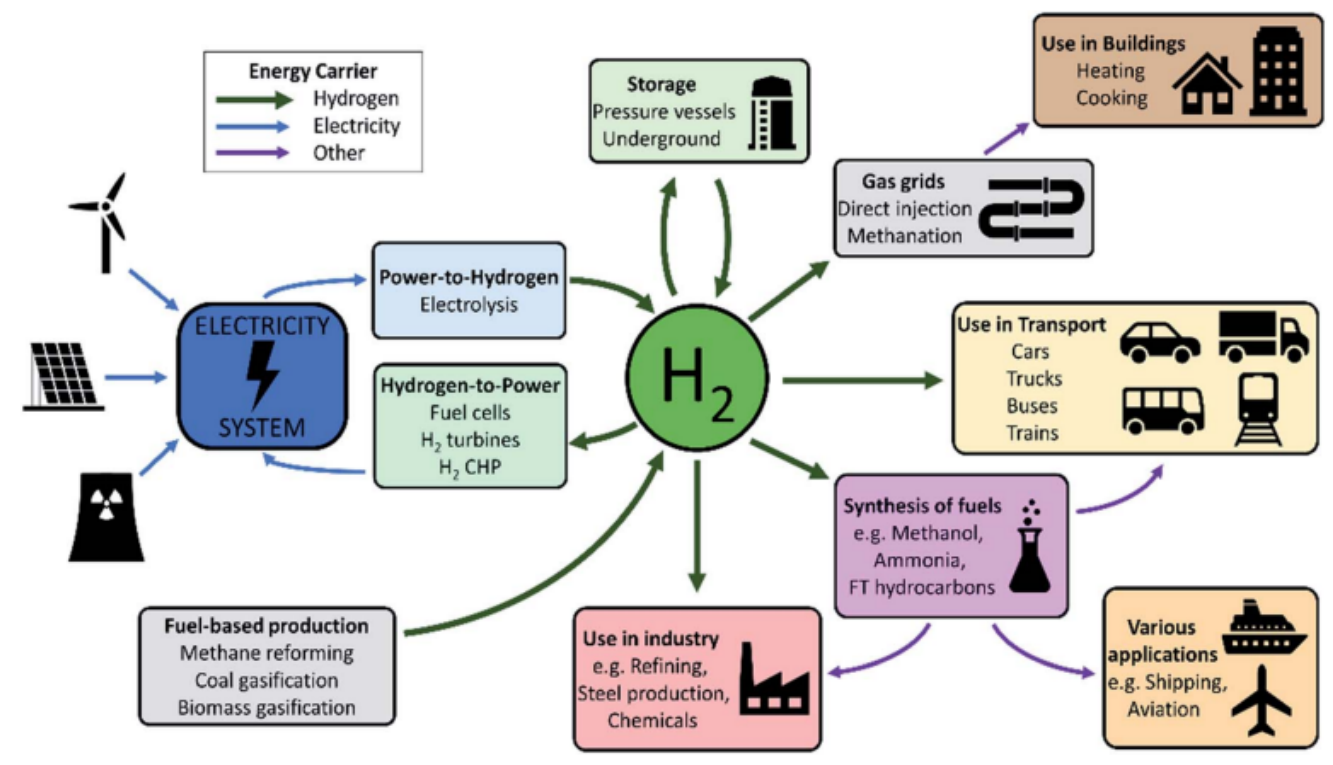

Figure 14. Utilization of hydrogen, Reproduced from ref. [109].

3.3.1. Hydrogen Fuel Cell in Automotive Market, Transport Industries, and Their Infrastructural Issues

The automotive fuel cell market is established by the Toyota Motor Corporation (Toyota, Japan), Ballard Power Systems (Burnaby, BC, Canada), Hyundai Group (Seoul, Korea), and others. These companies provide products and solutions for the automotive fuel cell industry and distribution networks at a global level to develop new products. The first hydrogen-based cars were introduced by Honda, Toyota, and Hyundai at almost the same time, and now are being followed by other brands to decarbonize the transport sector. In 2018, the market value of hydrogen fuel cell vehicles is $\$ 651.9$ million and predicted to increase by $66.9 \%$ in the period of 2019 to 2026 . The main factors that affect the development of the universal market are, from an environmental point of view, future 
potential, high investment, and development in hydrogen fuel cell infrastructure. All of these factors have a certain effect on the market of the hydrogen fuel cell vehicle [112]. Fuel cell electric vehicles (FCEVs) can provide a strong hold on the transportation market. Presently, Europe is emerging as a continent which has a wide range of hydrogen buses, among them, many are running in Chinese cities. European countries have a target of acquiring more than 1000 hydrogen-fueled buses by the year of 2023. For ideal fuel cell application this automotive market has characteristics such as longer driving range, higher fuel efficiency, and fast refueling of fuel cell [105].

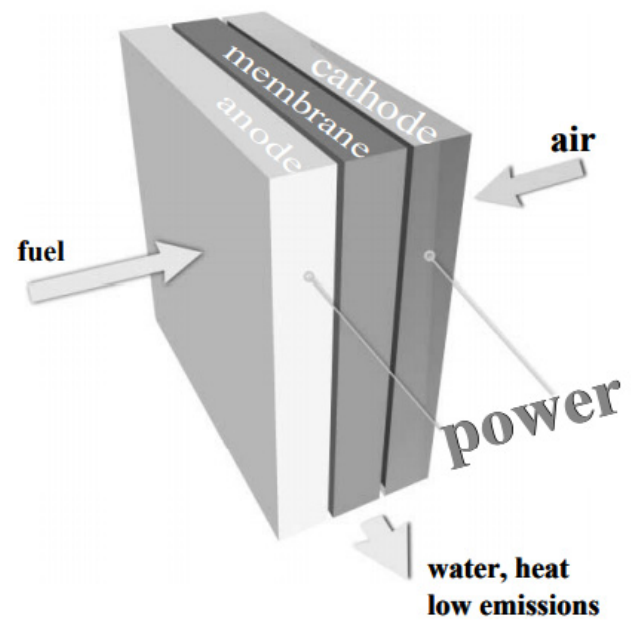

Figure 15. Schematic of fuel cell. Reproduced from ref. [50] with permission of Royal Society of London.

Utilization of hydrogen in the transportation sector, as a fuel in hydrogen fuel-cell vehicles to power electric motors, has potential to decrease emissions. They do not produce any greenhouse gas emissions as are produced by gasoline- and diesel-powered vehicles.

In adoption of FCEVs the main obstacle is its new and expensive infrastructure. According to a report there were almost 376 hydrogen refueling stations (HRS) globally in 2018, which is shown in Figure 16. Currently, these HRS are serving at a capacity of 10-90 FCVs per station. In future these are expected to increase to 2500-3500 FCEVs per station. Hence current infrastructure is limited and insufficient. At this stage of development, there is a need to establish infrastructure for FCEVs such as cars, buses, and trucks, which can use a central location to refuel. Through this modularization infrastructure costs could be meaningfully reduced [110]. Governments all over the world have organized numerous policies which provide environment-based circumstances. For example, California (U.S.) dedicated funds for the improvement of more than 100 hydrogen refueling stations to fulfill its goal of 1.5 million vehicles with zero-emission by the year 2025, increasing development of the market of the hydrogen fuel cell vehicle [112]. The improvement of infrastructure of hydrogen is a significant obstacle to the extensive uptake of hydrogen fuel cell techniques. The economy of hydrogen must be established with the vast cost and replication of infrastructure of the current energy system. Developing a cost-efficient infrastructure is a significant challenge. There are many commercial vehicles in the transportation sector such as fuel cell passenger vehicles, fuel cell electric buses, fuel cell light, and medium-duty trucks, and fuel cell heavy duty trucks which offer solutions for zero-emission as compared to ICE and diesel powered vehicles. Fuel-cell vehicles have short refueling time, i.e., they need only 3-5 min to refuel and they can also travel on a single tank for 250 to 350 miles as compared to ICE and diesel powered vehicles. Thus, FCEVs can satisfy noise guidelines and environmental conditions, which inspires the government to quicken their implementation, but the main obstacle is a shortage of extensive hydrogen infrastructure. If in future hydrogen infrastructure increases, it is estimated that private consumption will also increase. 


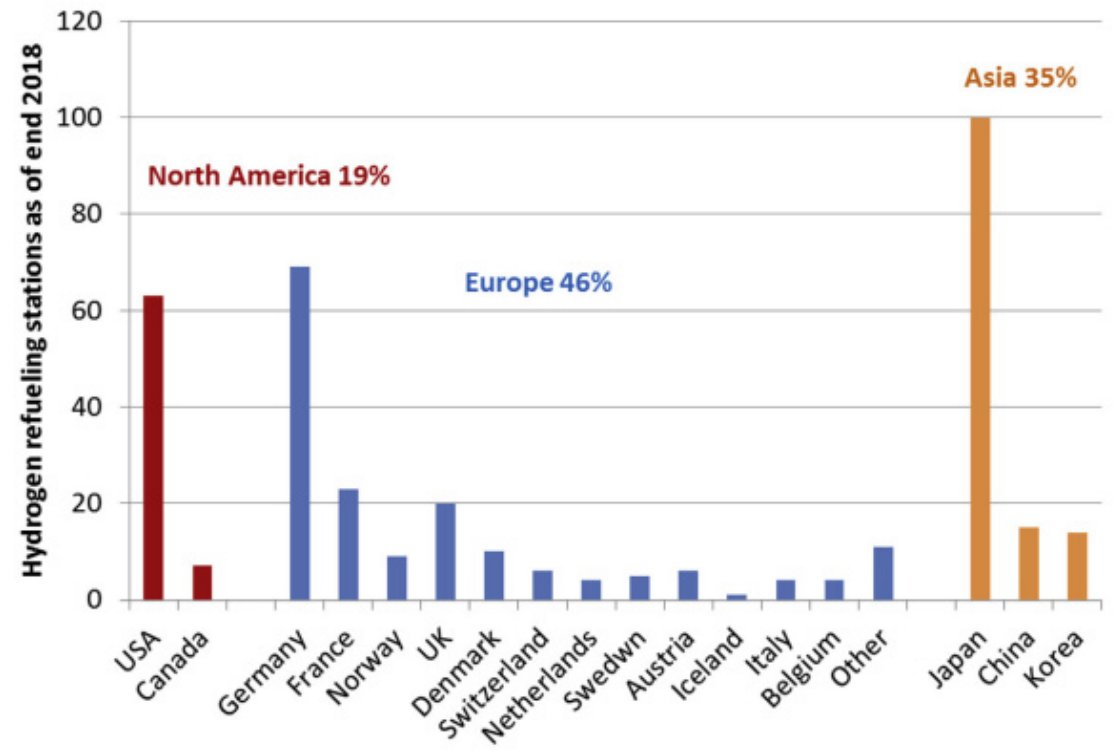

Figure 16. Hydrogen refueling stations at the end of 2018. Reproduced from ref. [110] with permission of Elsevier.

\subsubsection{Environmental Aspects}

Currently, the transportation sector mainly depends on fossil fuels and is responsible for a large amount of greenhouse gas emission. For lowering the emission of greenhouse gases, this sector needs to step forward towards the use of hydrogen as a fuel for vehicles. Numerous opportunities have been recommended for automotive applications to replace fossil fuel with hydrogen, for which the hydrogen fuel-cell electric vehicles seems to be a possibility for future transportation because they cause no significant pollution [24]. Various techniques are developed in the market to support eco-friendly and sustainable products to overcome the environment degradation and depletion of natural resources. Among them, the hydrogen fuel cell vehicles is a leading technology as it is eco-friendly compared to other conventional vehicles.

A fuel cell does not emit any kind of pollutant emissions because it emits only water when it is operated in a normal temperature range. Hydrogen-powered fuel cell vehicles produce zero emissions [113]. The fuel cells based on hydrocarbon fuel also provide comparatively cleaner, efficient energy, which contribute to the reduction in emission of greenhouse gases. In Figure 17, a city bus with a fuel cell engine and hydrogen as a fuel are shown running successfully in Japan, Germany, and the UK [114]. The environmental aspect is directly related to the emission of greenhouse gases for both fuel cell and conventional power generation. They both utilize fuel to extract energy. If we compare solid polymer fuel cells (SPFCs) and phosphoric acid fuel cell PAFC (types of fuel cell) to the conventional technologies for different applications like transportation and commercial power generation (Figure 18), it is clear that SPFCs and PAFCs gives less than $1 \mathrm{~g} / \mathrm{km}$ emission of greenhouse gases and result in lower emissions. Thus, these are more environmentally friendly compared to conventional power generation technologies and conventional vehicles which give the highest emission of greenhouse gases in the range of $3-5.95 \mathrm{~g} / \mathrm{km}$. The reduction amount of energy used by a fuel cell is almost $26-97.4 \%$ compared to others (CNG and batteries) [115].

\subsubsection{Economic Aspects}

In this section, the cost of fuel cell and challenges associated with it will be reviewed. Although fuel cells have an efficiency of almost $60-70 \%$ (higher than conventional engines), the cost of fuel cells is still higher. The higher thermal efficiency of the fuel cell significantly reduces the overall fuel bill, thus eliminate the problem of costly fuel cells. Moreover, in 2006 the cost of fuel cells had already reduced by $60 \%$ (Figure 19), which is expected to 
reduce more with further development of technology. In addition, in 2006 the durability of fuel cell had also increased in the order of 4 and now it is equal to 120,000 miles.

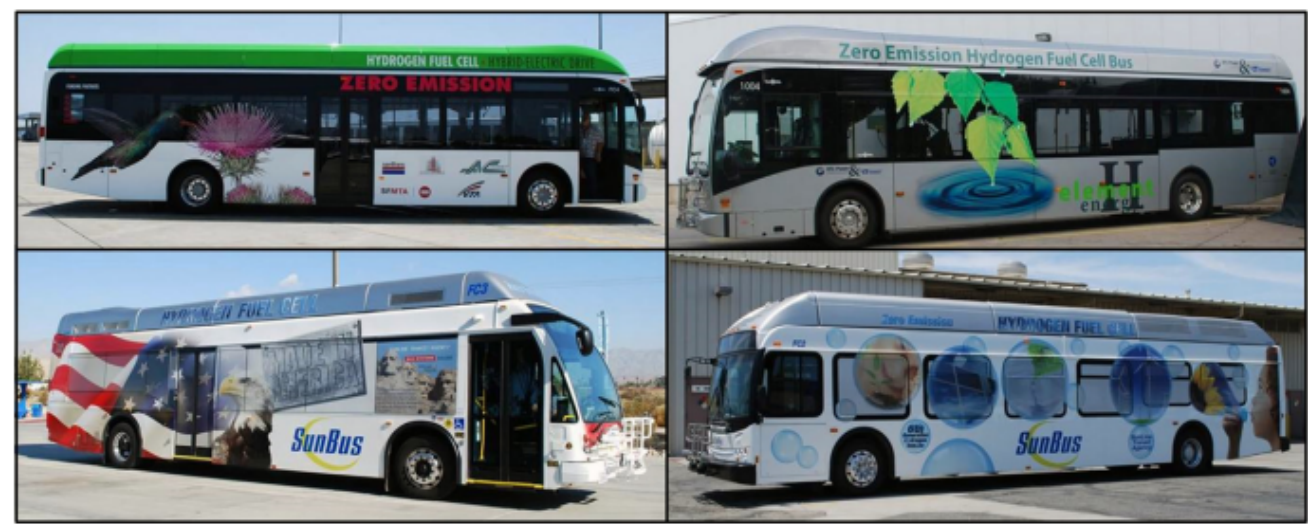

Figure 17. A city bus with a fuel cell engine, Reproduced from ref. [114] with permission of Elsevier.

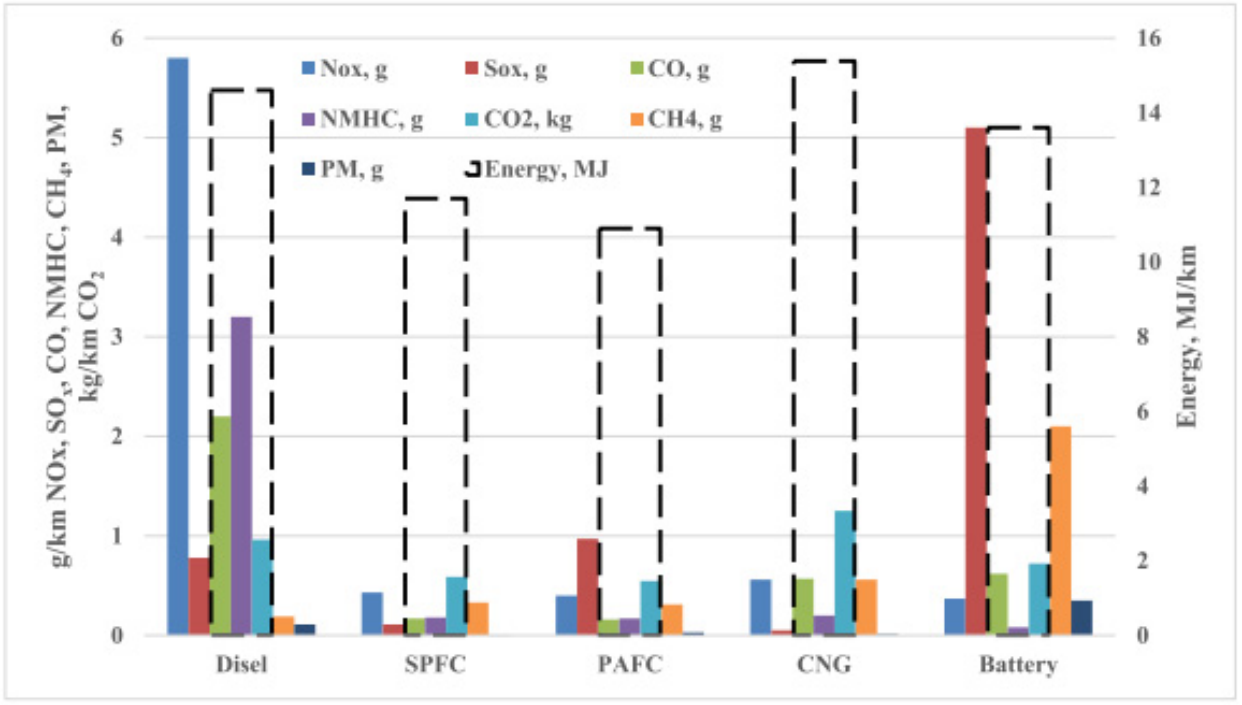

Figure 18. The gaseous emissions and energy of FC and batteries relative to conventional diesel bus technology. (SPFC = solid polymer fuel cell, $\mathrm{PAFC}=$ phosphoric acid fuel cell, $\mathrm{CNG}=$ compressed natural gas) Reproduced from ref. [115] with permission of Elsevier.

Modeled Cost of Fuel Cell System Over Time

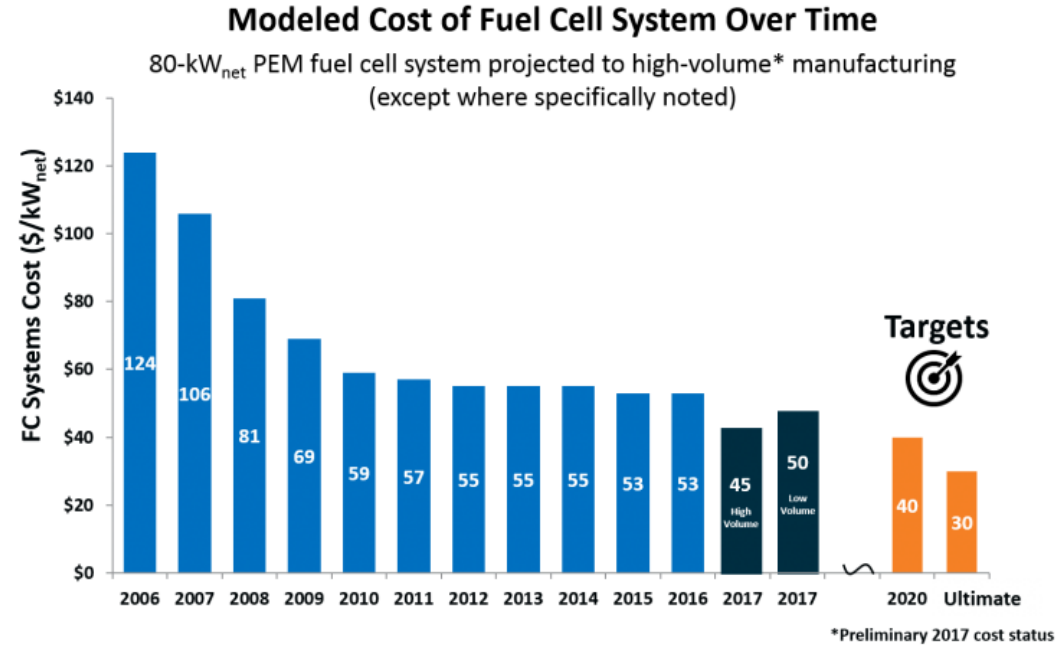

Figure 19. Cost of fuel cell system [116]. 
For wider use of FCEVs, the major hurdle is its affordability. Use of FCEVs and hydrogen are still very expensive compared to conventional cars and batteries. Hence, for commercialization of FCEVs, the main parameter is to reduce investment costs. For conventional cars, prices have been constant for several years. However, if we see the price differences between ICE vehicles and FCEVs, they are decreasing continuously over time, which can be seen in Figure 20.

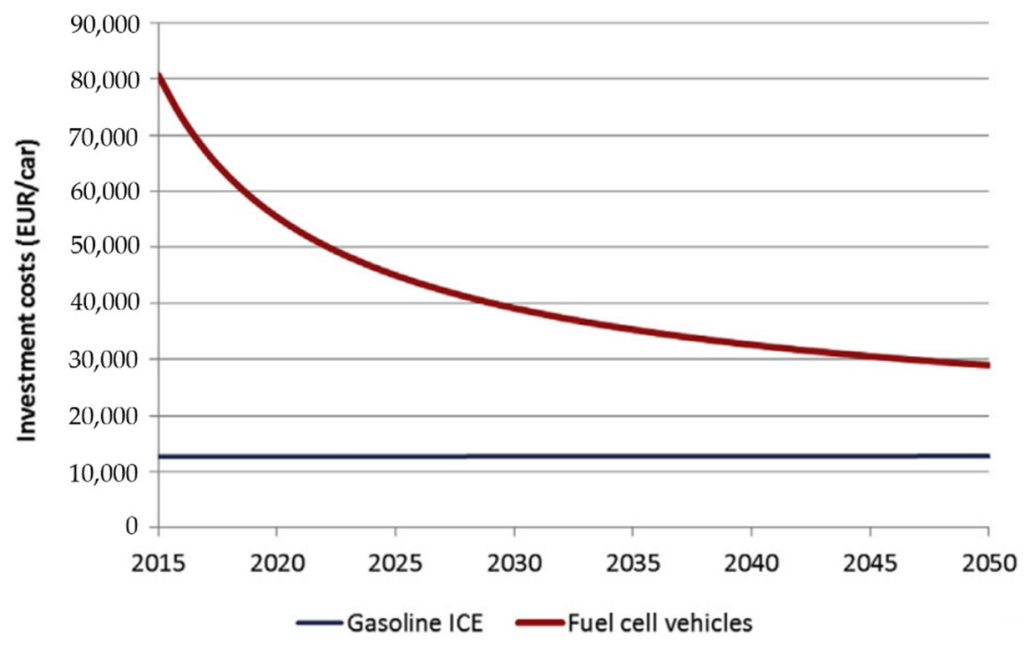

Figure 20. Development of the investment costs of vehicles. Reproduced from ref. [110] with permission of Elsevier.

Total mobility costs of FCEVs are dependent on the buying price of vehicles, Figure 21 shows total mobility costs for present and future FCEVs as compared to conventional ICE vehicles. In this, the driving range over 7 years is supposed to be $12,000 \mathrm{~km}$ per year. In the figure it is seen that in the current situation, total mobility costs of FCEVs are higher than to conventional ICE vehicles, but the cost of FCEVs decreases as compared to ICE vehicles in the future. On the other hand, FCEVs have zero-emissions at the point of use. So, we can say that in future it is better option to use FCEVs as compared to ICE vehicles.

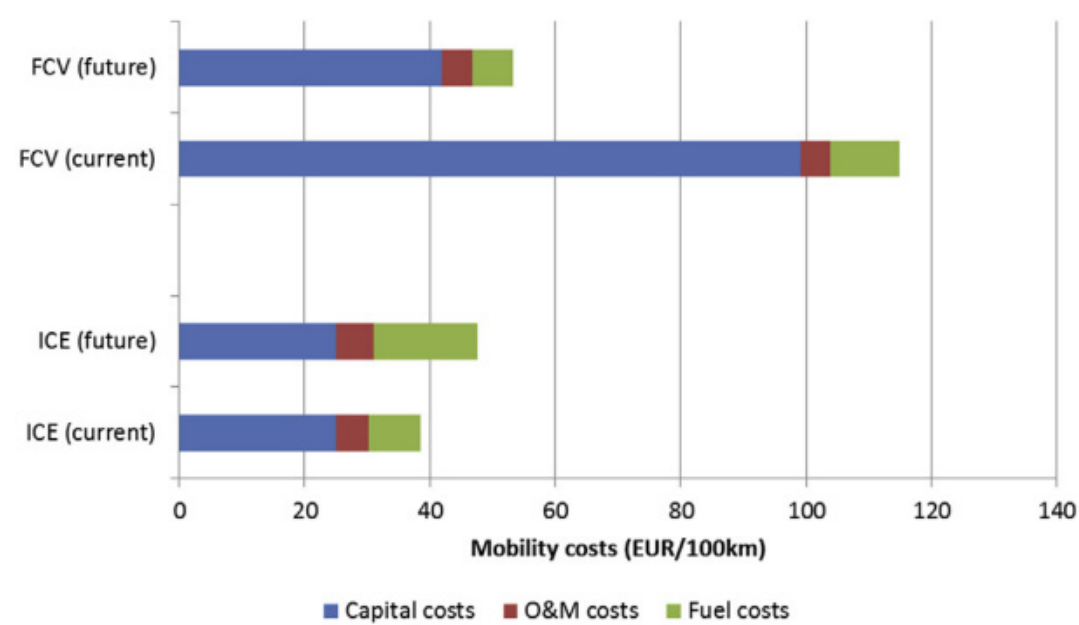

Figure 21. Total costs of mobility with FCVs as compared to ICE vehicles. Reproduced from ref. [110] with permission of Elsevier.

Thus, in summary, it can be concluded that fuel cells have the capability to change the present energy scenario based on hydrocarbon fuels, and will offer high-efficiency fuel in future, i.e., hydrogen. The major challenge with the fuel cell is their high cost, which needs to be lowered in the near future [50]. 


\subsection{Commercial Applications of Hydrogen}

As an alternative, hydrogen has become a promising fuel. Hydrogen has several applications but less than $10 \%$ is being used for global hydrogen consumption. For past decades and in the fossil fuel era, hydrogen has been used mainly by the petroleum refining industry, in the production of petrochemicals, agriculture industry, and chemical industry. Besides its industry uses, it has been used for things such as welding, electronics manufacturing, flat glass production, metal working. Other commercial applications of hydrogen include space exploration, public and personal transportations, power generations, and aviation where it is used as an alternative combustible fuel. The fuel cell is one of the auspicious commercialized applications opening new opportunities in the transportation and energy sector. In the transition era, hydrogen will be used as a chemical fuel [117], to produce electricity by fuel cells [118-120], manufacturing of synthetic fuels, aircraft, motor vehicles, etc. Hydrogen will be used in the hydrogen era as a prime fuel in energy systems, mainly in the transportation sector. Many countries are seeing emerging techniques that will use hydrogen in large scale in the future [60].

\subsection{Hydrogen Safety}

One of the central and most important aspects of hydrogen is the safety concern. It has been a matter of discussion how safely it can be used. As we look back into the literature, numerous investigations regarding the safety pointed out that the hydrogen does not appear as hazardous as fossil fuels. In fact, it is safer than gasoline and methane. Because of its non-toxic nature, leakage of hydrogen does not cause any environmental damage. Hydrogen has low density and for that purpose it disperses speedily as it rises, thus reducing the possibility of fire [121] up to a certain limit. However, once the concentration of hydrogen reaches more than $4 \%$ in the atmosphere, it may cause a serious fire or even explosion [122]. Hydrogen must be measured safely if accepted by the community. To address this concern, numerous solid-state hydrogen storage materials (metal hydrides) were developed as discussed above. These reduce the handling pressure of hydrogen gas and are comparatively safe for hydrogen storage. Confidence is necessary for increase the use of the fuel cell and other hydrogen-based technology. A significant feature in encouraging community confidence will be the improvement in product publicity, education projects, and marketing which provide the acceptance of hydrogen as a fuel [123].

\section{Conclusions}

The world-wide energy demand, which is dependent on fossil fuel-based energy system such as coal, oil, and natural gas, is becoming difficult to fulfil and it is also causing several environmental impacts. Gradually, fossil fuels should be replaced by alternative energy sources such as hydrogen energy, wind, nuclear, and solar energy. Hydrogen has ideal economic and environmental characteristics to become a future energy carrier, as it can be a clean, safe, and sustainable energy carrier with developing technologies of production, storage, and utilization. Utilizations of hydrogen are spreading in various industries, such as transportation and power generation, and are under development for several other applications. There are numerous commercial methods for $\mathrm{H}_{2}$ production such as steam methane reforming, partial oxidation of hydrocarbons, coal gasification, biomass gasification, pyrolysis, electrolysis, and the thermochemical method; electrolysis and solar energy methods are going to be the prominent methods in future according to an environmental point of view. Hydrogen storage methods need to undergo more research and development. Hydrogen can be stored in gaseous, liquid, and solid chemical form. Out of these methods, solid state storage shows promise and has potential to be widely accepted. From economic aspects, the cost of hydrogen production is the most important factor and other factors such as costs of utilization and storage are comparatively small [124].

The information presented in this review is based on the present renewable-based energy system and its application in the automotive industry, which emphasizes the tenden- 
cies in worldwide energy consumption, and development in reducing the dependency on a fossil fuel-based energy infrastructure. In total global emissions, numerous fuel sources contribute, several energy systems among them, and the automotive industry being a chief contributors.

FCEVs can be seen as a prominent contender towards the conversion of the present transport system, which is based on fossil fuels, to a sustainable system. The transportation sector has had several up gradations and degradations with respect to time. In the transportation sector, FCEVs could be a better option than conventional ICE vehicles. In future, there are some challenges which must be solved, such as cost reduction of cars and development of infrastructures. This review provides direction for the development of fuel-cell vehicles with the aim of reducing worldwide environmental pollution. In future, the problems in developing FCEVs can be studied for their implementations. However, the costs of fuel cell vehicles are higher than those of battery electric vehicles, but their practical implementations can be achieved in the period of 2025 to 2030 . Further, the research and development in solving the various issues in FCEVs will position FCEVs in the future. In addition, in future, the automobile industry will be powered by hybrid systems which have the capacity to utilize the benefits of both energy system, i.e., renewable and fuel cell-based energy systems. Beside this, hydrogen fuel in the form of fuel cells will be the game changer in the portable power supplies in future. Therefore, it can be concluded that hydrogen-based fuel cells would certainly contribute globally to the improvement of a sustainable humanity.

Thus, we can say that by choosing the most prominent and sustainable production and storage methods, and by improving the automotive applications such as fuel cell-based electric vehicles, the dominant role of fossil fuels in energy systems could be reduced and it will not be so long until the world will enter the "hydrogen era".

Author Contributions: Conceptualization: A.J.; writing-original draft preparation: S.S.; writingreview and editing: S.A., A.J.; supervision: S.A. and A.J. All authors have read and agreed to the published version of the manuscript.

Funding: No funding is received.

Institutional Review Board Statement: Not applicable.

Informed Consent Statement: Not applicable.

Data Availability Statement: No data is reported here, all the data supplied here is from other papers as it is review article.

Conflicts of Interest: The authors declare no conflict of interest.

\section{References and Notes}

1. Apostolou, D.; Xydis, G. A literature review on hydrogen refueling stations and infrastructure, Current status and future prospectus. Renew. Sustain. Energy Rev. 2019, 113, 109292. [CrossRef]

2. Dincer, I.; Acar, C. Smart energy solutions with hydrogen options. Int. J. Hydrogen Energy 2018, 43, 8579-8599. [CrossRef]

3. Khan, N.; Kalair, E.; Abas, N.; Kalair, A. Energy transition from molecules to atoms and photons. Eng. Sci. Technol. Int. J. 2019, 22, 185-214. [CrossRef]

4. To, W.-M.; Lee, P.K.C. Energy Consumption and Economic Development in Hong Kong, China. Energies 2017, 10, 1883. [CrossRef]

5. Mohsin, M.; Kamran, H.W.; Nawaz, M.A.; Hussain, M.S.; Dahri, A.S. Assessing the impact of transition from non-renewable to renewable energy consumption on economic growth-environmental nexus from developing Asian economies. J. Environ. Manag. 2021, 284, 111999. [CrossRef] [PubMed]

6. BPSTATS. BP Statistical Review of World Energy Statistical Review of World, 68th ed.; Heriot-Watt University: Edinburgh, UK, 2019.

7. Enerdata. Enerdata: Global Energy Statistical Yearbook 2018. Global Energy Trends. 2018. Available online: https://energydata. info/dataset/key-world-energy-statistics-enerdata/resource/dcda6530-8d2c-436e-9d1d-1e2809ad303e (accessed on 2 November 2021).

8. Norton, R. An Overview of a Sustainable City Strategy. Report Prepared for the Global Energy Assessment Planning for Cities and Municipalities. Montreal, QC, Canada, 1991.

9. Dincer, I.; Rosen, M.A. A worldwide perspective on energy, environment and sustainable development. Int. J. Energy Res. 1998, 22, 1305-1321. [CrossRef] 
10. Rosen, M. The role of energy efficiency in sustainable development. In Proceedings of the 1995 Interdisciplinary Conference: Knowledge Tools for a Sustainable Civilization, Fourth Canadian Conference on Foundations and Applications of General Science Theory, Toronto, ON, Canada, 8-10 June 1995. [CrossRef]

11. Solomon, B.D.; Banerjee, A. A global survey of hydrogen energy research, development and policy. Energy Policy 2006, 34, 781-792. [CrossRef]

12. Zuttel, A.; Remhof, A.; Borgschulte, A. Hydrogen: The future energy carrie. Philos. Trans. R. Soc. A 2010, 368, 3329-3342. [CrossRef] [PubMed]

13. Rosen, M.A.; Dincer, I.; Kanoglu, M. Role of exergy in increasing efficiency and sustainability and reducing environmental impact. Energy Policy 2008, 36, 128-137. [CrossRef]

14. IEA. From Poverty to Prosperity. In World Energy Outlook Special Report; OECD Publishing: Paris, France, 2017. Available online: https:/ / www.oecd.org/publications/energy-access-outlook-2017-9789264285569-en.htm (accessed on 19 February 2020).

15. Berrill, P.; Arvesen, A.; Scholz, Y.; Gils, H.C.; Hertwich, E. Environmental impacts of high penetration renewable energy scenarios for Europe. Environ. Res. Lett. 2016, 11, 014012. [CrossRef]

16. Dunn, S. Hydrogen futures: Toward a sustainable energy system. Int. J. Hydrogen Energy 2002, 27, 235-264. [CrossRef]

17. Dincer, I.; Rosen, M.A. Sustainability aspects of hydrogen and fuel cell systems. Energy Sustain. Dev. 2011, 15, 137-146. [CrossRef]

18. Boyle, G. Renewable energy: Power for a sustainable future. Renew. Energy 2004, 19, 456.

19. Schlapbach, L.; Züttel, A. Hydrogen-storage materials for mobile applications. Nat. Cell Biol. 2001, 414, 353-358. [CrossRef] [PubMed]

20. Carbon-Based Nanoporous Materials for Hydrogen Storage. Available online: https://pure.unileoben.ac.at/portal/files/221436 7/AC14528127n01-2017 (accessed on 30 November 2017).

21. Nowotny, J.; Veziroglu, T.N. Impact of hydrogen on the environment. Int. J. Hydrogen Energy 2011, 36, 13218-13224. [CrossRef]

22. Hydrogen Council. Path to Hydrogen Competitiveness a Cost Perspective; Hydrogen Council: Brussels, Belgium, $2020 ;$ pp. 1-88.

23. Hydrogen Council. Hydrogen Scaling up, a Sustainable Pathway for the Global Energy Transition; Hydrogen Council: Brussels, Belgium, 2017; pp. 1-80.

24. Rosen, M.A.; Koohi-Fayegh, S. The prospects for hydrogen as an energy carrier: An overview of hydrogen energy and hydrogen energy systems. Energy Ecol. Environ. 2016, 1, 10-29. [CrossRef]

25. Atilhan, S.; Park, S.; El-Halwagi, M.M.; Atilhan, M.; Moore, M.; Nielsen, R.B. Green hydrogen as an alternative fuel for the shipping industry. Curr. Opin. Chem. Eng. 2021, 31, 100668. [CrossRef]

26. Global hydrogen market insights, 2020-2024 by production process, end-user, generation system and region. Focus Catal. 2020, 5,2 .

27. Osman, A.I.; Mehta, N.; Elgarahy, A.M.; Hefny, M.; Al-Hinai, A.; Al-Muhtaseb, A.H.; Rooney, D.W. Hydrogen production, storage, utilisation and environmental impacts: A review. Environ. Chem. Lett. 2021, 1-36. [CrossRef]

28. Nicoletti, G.; Arcuri, N.; Nicoletti, G.; Bruno, R. A technical and environmental comparison between hydrogen and some fossil fuels. Energy Convers. Manag. 2015, 89, 205-213. [CrossRef]

29. Dincer, I.; Zamfirescu, C. Sustainable hydrogen production options and the role of IAHE. Int. J. Hydrogen Energy 2012, 37, 16266-16286. [CrossRef]

30. Chaubey, R.; Sahu, S.; James, O.O.; Maity, S. A review on development of industrial processes and emerging techniques for production of hydrogen from renewable and sustainable sources. Renew. Sustain. Energy Rev. 2013, 23, 443-462. [CrossRef]

31. Acar, C.; Dincer, I. Comparative assessment of hydrogen production methods from renewable and non-renewable sources. Int. J. Hydrogen Energy 2014, 39, 1-12. [CrossRef]

32. Dincer, I.; Acar, C. Review and evaluation of hydrogen production methods for better sustainability. Int. J. Hydrogen Energy 2015, 40, 11094-11111. [CrossRef]

33. Enger, B.C.; Lødeng, R.; Holmen, A. A review of catalytic partial oxidation of methane to synthesis gas with emphasis on reaction mechanisms over transition metal catalysts. Appl. Catal. A Gen. 2008, 346, 1-27. [CrossRef]

34. Agrafiotis, C.; von Storch, H.; Roeb, M.; Sattler, C. Solar thermal reforming of methane feedstocks for hydrogen and syngas production-A review. Renew. Sustain. Energy Rev. 2014, 29, 656-682. [CrossRef]

35. Barelli, L.; Bidini, G.; Gallorini, F.; Servili, S. Hydrogen production through sorption-enhanced steam methane reforming and membrane technology: A review. Energy 2008, 33, 554-570. [CrossRef]

36. Amin, A.; Croiset, E.; Epling, W. Review of methane catalytic cracking for hydrogen production. Int. J. Hydrogen Energy 2011, 36, 2904-2935. [CrossRef]

37. Abbas, H.F.; Daud, W.W. Hydrogen production by methane decomposition: A review. Int. J. Hydrogen Energy 2010, 35, 1160-1190. [CrossRef]

38. Demirci, U.B. The hydrogen cycle with the hydrolysis of sodium borohydride: A statistical approach for highlighting the scientific/technical issues to prioritize in the field. Int. J. Hydrogen Energy 2015, 40, 2673-2691. [CrossRef]

39. Patel, N.; Miotello, A. Progress in Co-B related catalyst for hydrogen production by hydrolysis of boron-hydrides: A review and the perspectives to substitute noble metals. Int. J. Hydrogen Energy 2015, 40, 1429-1464. [CrossRef]

40. Liu, B.H.; Li, Z.P. A review: Hydrogen generation from borohydride hydrolysis reaction. J. Power Sources 2009, 187, 527-534. [CrossRef] 
41. Moussa, G.; Moury, R.; Demirci, U.B.; Sener, T.; Miele, P. Boron-based hydrides for chemical hydrogen storage. Int. J. Energy Res. 2013, 37, 825-842. [CrossRef]

42. Rand, D.A.J.; Dell, R.M. Fuels-hydrogen production: Coal gasification. EncyclElecrochem Power Sources 2009, $276-292$.

43. Hallenbeck, P.C.; Abo-Hashesh, M.; Ghosh, D. Strategies for improving biological hydrogen production. Bioresour. Technol. 2012, 110, 1-9. [CrossRef] [PubMed]

44. Eroglu, E.; Melis, A. Photo biological hydrogen production: Recent advances and state of the art. Bioresour. Technol. 2011, 102, 8403-8413. [CrossRef]

45. Lee, H.-S.; Vermaas, W.F.; Rittmann, B.E. Biological hydrogen production: Prospects and challenges. Trends Biotechnol. 2010, 28, 262-271. [CrossRef]

46. Singh, L.; Wahid, Z.A. Methods for enhancing bio-hydrogen production from biological process: A review. J. Ind. Eng. Chem. 2015, 21, 70-80. [CrossRef]

47. Zhang, Q.; Wang, Y.; Zhang, Z.; Lee, D.-J.; Zhou, X.; Jing, Y.; Ge, X.; Jiang, D.; Hu, J.; He, C. Photo-fermentative hydrogen production from crop residue: A mini review. Bioresour. Technol. 2017, 229, 222-230. [CrossRef] [PubMed]

48. Elsharnouby, O.; Hafez, H.; Nakhla, G.; El Naggar, M.H. A critical literature review on biohydrogen production by pure cultures. Int. J. Hydrogen Energy 2013, 38, 4945-4966. [CrossRef]

49. Sivagurunathan, P.; Kumar, G.; Bakonyi, P.; Kim, S.-H.; Kobayashi, T.; Xu, K.; Lakner, G.; Tóth, G.; Nemestothy, N.; Bélafi-Bakó, $\mathrm{K}$. A critical review on issues and overcoming strategies for the enhancement of dark fermentative hydrogen production in continuous systems. Int. J. Hydrogen Energy 2016, 41, 3820-3836. [CrossRef]

50. Edwards, P.P.; Kuznetsov, V.L.; David, W.I.F. Hydrogen energy. Philos. Trans. R. Soc. A 2007, 365, 1043-1056. [CrossRef] [PubMed]

51. Steinberg, M. Modern and prospective technologies for hydrogen production from fossil fuels. Int. J. Hydrogen Energy 1989, 14, 797-820. [CrossRef]

52. Bartels, J.R.; Pate, M.B.; Olson, N.K. An economic survey of hydrogen production from conventional and alternative energy sources. Int. J. Hydrogen Energy 2010, 35, 8371-8384. [CrossRef]

53. Yan, W.; Hoekman, K. Production of $\mathrm{CO}_{2}$-free hydrogen from methane dissociation: A review. Environ. Prog. Sustain. Energy 2014, 33, 213-219. [CrossRef]

54. Gaudernack, B.; Lynum, S. Hydrogen from natural gas without release of $\mathrm{CO}_{2}$ to the atmosphere. Int. J. Hydrogen Energy 1998, 23, 1087-1093. [CrossRef]

55. Ashik, U.P.M.; Daud, W.M.A.W.; Abbas, H.F. Production of greenhouse gas free hydrogen by thermo catalytic decomposition of methane a review. Renew. Sustain. Energy Rev. 2015, 44, 221-256. [CrossRef]

56. Damen, K.; van Troost, M.; Faaij, A.; Turkenburg, W. A comparison of electricity and hydrogen production systems with $\mathrm{CO}_{2}$ capture and storage. Part A: Review and selection of promising conversion and capture technologies. Prog. Energy Combust. Sci. 2006, 32, 215-246. [CrossRef]

57. Nikolaidis, P.; Poullikkas, A. A comparative overview of hydrogen production processes. Renew. Sustain. Energy Rev. 2017, 67, 597-611. [CrossRef]

58. Bonner, M.; Botts, T.; McBreen, J.; Mezzina, A.; Salzano, F.; Yang, C. Status of advanced electrolytic hydrogen production in the United States and abroad. Int. J. Hydrogen Energy 1984, 9, 269-275. [CrossRef]

59. Carpetis, C. An assessment of electrolytic hydrogen production by mans of photovoltaic energy conversion. Int. J. Hydrogen Energy 1984, 9, 969-992. [CrossRef]

60. Johnson, A.C.; Barnstaple, A.G.; Bates, J.G.; Boardman, B.R.; Dewees, D.N.; Fleck, F.C.; Taylor, J.B.; Schofield, L.J.; Soots, V.; Wank, H. Hydrogen, a Challenging Opportunity. Report of the Ontario Hydrogen Energy Task Force; Ontario Government Publications Services: Toronto, ON, Canada, 1981.

61. Baykara, S.Z.; Bilgen, E. An overall assessment of hydrogen production by solar water thermolysis. Int. J. Hydrogen Energy 1989, 14, 881-891. [CrossRef]

62. Baykara, S. Hydrogen production by direct solar thermal decomposition of water, possibilities for improvement of process efficiency. Int. J. Hydrogen Energy 2004, 29, 1451-1458. [CrossRef]

63. Baykara, S.Z. Experimental solar water thermolysis. Int. J. Hydrogen Energy 2004, 29, 1459-1469. [CrossRef]

64. Bhandari, R.; Trudewind, C.A.; Zapp, P. Life cycle assessment of hydrogen production via Electrolysis-A review. J. Clean. Prod. 2014, 85, 151-163. [CrossRef]

65. Muradov, N.Z.; Veziroglu, T.N. “Green” path from fossil-based to hydrogen economy: An overview of carbon-neutral technologies Int. J. Hydrogen Energy 2008, 33, 6804-6839. [CrossRef]

66. Turner, J.; Sverdrup, G.; Mann, M.K.; Maness, P.C.; Kroposki, B.; Ghirardi, M.; Evans, R.J.; Blake, D. Renewable hydrogen production. Int. J. Energy Res. 2008, 32, 379-407. [CrossRef]

67. Yildiz, B.; Kazimi, M.S. Efficiency of hydrogen production systems using alternative nuclear energy technologies. Int. J. Hydrogen Energy 2006, 31, 77-92. [CrossRef]

68. Dieguez, P.; Ursúa, A.; Sanchis, P.; Sopena, C.; Guelbenzu, E.; Gandia, L. Thermal performance of a commercial alkaline water electrolyzer: Experimental study and mathematical modeling. Int. J. Hydrogen Energy 2008, 33, 7338-7354. [CrossRef]

69. Funk, J.E. Thermochemical hydrogen production: Past and present. Int. J. Hydrogen Energy 2001, 26, 185-190. [CrossRef]

70. Lewis, M.A.; Masin, J.G. The evaluation of alternative thermochemical cycles-Part II: The down-selection process. Int. J. Hydrogen Energy 2009, 34, 4125-4135. [CrossRef] 
71. Andress, R.J.; Huang, X.; Bequette, B.W.; Martin, L.L. A systematic methodology for the evaluation of alternative thermochemical cycles for hydrogen production. Int. J. Hydrogen Energy 2009, 34, 4146-4154. [CrossRef]

72. Forsberg, C.W.; Peterson, P.F.; Pickard, P.S. Molten-Salt-Cooled Advanced High-Temperature Reactor for Production of Hydrogen and Electricity. Nucl. Technol. 2003, 144, 289-302. [CrossRef]

73. Forsberg, C.W. Future hydrogen markets for large-scale hydrogen production systems. Int. J. Hydrogen Energy 2007, 32, 431-439. [CrossRef]

74. Acar, C.; Dincer, I. Comparative Environmental Impact Evaluation of Hydrogen Production Methods from Renewable and Nonrenewable Sources. In Causes, Impacts and Solutions to Global Warming; Springer Science and Business Media LLC: Berlin/Heidelberg, Germany, 2013; pp. 493-514.

75. Schultz, K.; Herring, S.; Lewis, M.; Summers, W. The hydrogen reaction. Nucl. Eng. Int. 2005, 50, 10-19.

76. Orhan, M.; Dincer, I.; Naterer, G. Cost analysis of a thermochemical Cu-Cl pilot plant for nuclear-based hydrogen production. Int. J. Hydrogen Energy 2008, 33, 6006-6020. [CrossRef]

77. Ursúa, A.; Gandia, L.M.; Sanchis, P. Hydrogen Production from Water Electrolysis: Current Status and Future Trends; IEEE: Piscataway, NJ, USA, 2011; Volume 100, pp. 410-426.

78. Srinivasan, N.; Shiga, Y.; Atarashi, D.; Sakai, E.; Miyauchi, M. A PEDOT-coated quantum dot as efficient visible light harvester for photocatalytic hydrogen production. Appl. Catal. B Environ. 2015, 179, 113-121. [CrossRef]

79. Engels, H.; Funk, J.E.; Hesselmann, K.; Knoche, K.F. Thermochemical hydrogen production. Int. J. Hydrogen Energy 1987, 12, 291-295. [CrossRef]

80. Bargigli, S.; Raugei, M.; Ulgiati, S. Comparison of thermodynamic and environmental indexes of natural gas, syngas and hydrogen production processes. Energy 2004, 29, 2145-2159. [CrossRef]

81. Chiesa, P.; Consonni, S.; Kreutz, T. Co-production of hydrogen, electricity and CO from coal with commercially ready technology. Part A: Performance and emissions. Int. J. Hydrogen Energy 2005, 30, 747-767. [CrossRef]

82. Cohce, M.; Dincer, I.; Rosen, M. Thermodynamic analysis of hydrogen production from biomass gasification. Int. J. Hydrogen Energy 2010, 35, 4970-4980. [CrossRef]

83. Sazali, N. Emerging technologies by hydrogen: A review. Int. J. Hydrogen Energy 2020, 45, 18753-18771. [CrossRef]

84. Suleman, F.; Dincer, I.; Agelin-Chaab, M. Environmental impact assessment and comparison of some hydrogen production options. Int. J. Hydrogen Energy 2015, 40, 6976-6987. [CrossRef]

85. Baykara, S.Z. Hydrogen: A brief overview on its sources, production and environmental impact. Int. J. Hydrogen Energy 2018, 43, 10605-10614. [CrossRef]

86. Baykara, S.Z. Hydrogen as fuel: A critical technology? Int. J. Hydrogen Energy 2005, 30, 545-553. [CrossRef]

87. Kothari, R.; Buddhiand, D.; Sawhney, R.L. Comparison of environmental and economic aspects of various hydrogen production methods. Renew. Sustain. Energy Rev. 2008, 12, 553-563. [CrossRef]

88. Ajanovic, A. On the economics of hydrogen from renewable energy sources as an alternative fuel in transport sector in Austria. Int. J. Hydrogen Energy 2008, 33, 4223-4234. [CrossRef]

89. Sara, H.R.; Enrico, B.; Mauro, V.; Andrea, D.C.; Vincenzo, N. Techno-economic Analysis of Hydrogen Production Using Biomass Gasification-A Small Scale Power Plant Study. Energy Procedia 2016, 101, 806-813. [CrossRef]

90. Sharma, M.; Kaushik, A. Biohydrogen Economy: Challenges and Prospects for Commercialization. In Biohydrogen Production: Sustainability of Current Technology and Future Perspective; Springer Science and Business Media LLC: Berlin/Heidelberg, Germany, 2017; pp. 253-267.

91. Hay, J.X.W.; Wu, T.Y.; Juan, J.C.; Jahim, J.M. Biohydrogen production through photo fermentation or dark fermentation using waste as a substrate: Overview, economics, and future prospects of hydrogen usage. Biofuels Bioprod. Biorefin. 2013, 7, 334-352. [CrossRef]

92. Kalamaras, C.; Efstathiou, A.M. Hydrogen Production Technologies: Current State and Future Developments. Conf. Pap. Energy 2013, 2013, 690627. [CrossRef]

93. Zuttel, A.; Borgschulte, A.; Schlapbach, L. Hydrogen as a future energy Carrier. J. Appl. Electrochem. 2008, $38,1483$.

94. Sakintuna, B.; Lamari-Darkrim, F.; Hirscher, M. Metal hydride materials for solid hydrogen storage: A review. Int. J. Hydrogen Energy 2007, 32, 1121-1140. [CrossRef]

95. Sreedhar, I.; Kamani, K.M.; Kamani, B.M.; Reddy, B.M.; Venugopal, A. A Bird's Eye view on process and engineering aspects of hydrogen storage. Renew. Sustain. Energy Rev. 2018, 91, 838-860. [CrossRef]

96. Suh, M.P.; Park, H.J.; Prasad, T.K.; Lim, D.W. Hydrogen storage in metal-organic frameworks. Chem. Rev. 2012, 112, 782-835. [CrossRef] [PubMed]

97. Jain, A.; Agarwal, S.; Ichikawa, T. Catalytic Tuning of Sorption Kinetics of Lightweight Hydrides: A Review of the Materials and Mechanism. Catalysts 2018, 8, 651. [CrossRef]

98. Yang, J.; Sudik, A.; Wolverton, C.; Siegel, D.J. High capacity hydrogen storage materials: Attributes for automotive applications and techniques for materials discovery. Chem. Soc. Rev. 2010, 39, 656-675. [CrossRef] [PubMed]

99. Jain, A.; Miyaoka, H.; Ichikawa, T. Destabilization of lithium hydride by the substitution of group 14 elements: A review. Int. J. Hydrogen Energy 2016, 41, 5969-5978. [CrossRef]

100. Jain, I.; Lal, C.; Jain, A. Hydrogen storage in Mg: A most promising material. Int. J. Hydrogen Energy 2010, 35, 5133-5144. [CrossRef] 
101. Wang, H.; Lin, H.; Cai, W.; Ouyang, L.; Zhu, M. Tuning kinetics and thermodynamics of hydrogen storage in light metal element based systems-A review of recent progress. J. Alloy. Compd. 2016, 658, 280-300. [CrossRef]

102. Hu, M.; Geanangel, R.; Wendlandt, W. The thermal decomposition of ammonia borane. Thermochim. Acta 1978, 23, 249-255. [CrossRef]

103. Klerke, A.; Christensen, C.H.; Nørskov, J.K.; Vegge, T. Ammonia for hydrogen storage: Challenges and opportunities. J. Mater. Chem. 2008, 18, 2304-2310. [CrossRef]

104. Jain, I.P.; Jain, A. Novel hydrogen storage materials: A review of light weight complex hydrides. J. Alloys Compd. 2010, 503, 303-339. [CrossRef]

105. Frank, E.D.; Elgowainy, A.; Khalid, Y.S.; Peng, J.-K.; Reddi, K. Refueling-station costs for metal hydride storage tanks on board hydrogen fuel cell vehicles. Int. J. Hydrogen Energy 2019, 44, 29849-29861. [CrossRef]

106. Reuß, M.; Grube, T.; Robinius, M.; Preuster, P.; Wasserscheid, P.; Stolten, D. Seasonal storage and alternative carriers: A flexible hydrogen supply chain model. Appl. Energy 2017, 200, 290-302. [CrossRef]

107. Raab, M.; Maier, S.; Dietrich, R.-U. Comparative techno-economic assessment of a large-scale hydrogen transport via liquid transport media. Int. J. Hydrogen Energy 2021, 46, 11956-11968. [CrossRef]

108. Cardella, U.; Decker, L.; Sundberg, J.; Klein, H. Process optimization for large-scale hydrogen liquefaction. Int. J. Hydrogen Energy 2017, 42, 12339-12354. [CrossRef]

109. Quarton, C.J.; Tlili, O.; Welder, L.; Mansilla, C.; Blanco, H.; Heinrichs, H.; Leaver, J.; Samsatli, N.J.; Lucchese, P.; Robinius, M.; et al. The curious case of the conflicting roles of hydrogen in global energy scenarios. Sustain. Energy Fuels 2020, 4, 80-95. [CrossRef]

110. Ajanovic, A.; Haas, R. Prospects and impediments for hydrogen and fuel cell vehicles in the transport sector. Int. J. Hydrogen Energy 2021, 46, 10049-10058. [CrossRef]

111. Dutton, A.G. Hydrogen Energy Technology, Tyndall Working Paper TWP 17; Tyndall Centre for Climate Change: Norwich, UK, 2002; Volume 30.

112. Available online: https://www.alliedmarketresearch.com/hydrogen-fuel-cell-vehicle-market-2021 (accessed on 2 November 2021).

113. Winter, M.; Brodd, R.J. What are batteries, fuel cells, and super capacitors? Chem. Rev. 2004, 104, 4245-4269. [CrossRef]

114. Hua, T.; Ahluwalia, R.; Eudy, L.; Singer, G.; Jermer, B.; Asselin-Miller, N.; Wessel, S.; Patterson, T.; Marcinkoski, J. Status of hydrogen fuel cell electric buses worldwide. J. Power Sources 2014, 269, 975-993. [CrossRef]

115. Abdelkareem, M.A.; Elsaid, K.; Wilberforce, T.; Kamil, M.; Sayed, E.T.; Olabi, A. Environmental aspects of fuel cells: A review. Sci. Total Environ. 2021, 752, 141803. [CrossRef] [PubMed]

116. Fact of the Month April 2018: Fuel Cell Cost Decreased by 60\% Since 2006. Available online: https://www.energy.gov/eere/ fuelcells / fact-month-april-2018-fuel-cell-cost-decreased-60-2006 (accessed on 2 November 2021).

117. Lattin, W.; Utgikar, V. Transition to hydrogen economy in the United States: A 2006 status report. Int. J. Hydrogen Energy 2007, 32, 3230-3237. [CrossRef]

118. Ball, M.; Weeda, M. The hydrogen economy: Vision or reality? Int. J. Hydrogen Energy 2015, 40, 7903-7919. [CrossRef]

119. Granovskii, M.; Dincer, I.; Rosen, M.A. Life cycle assessment of hydrogen fuel cell and gasoline vehicles. Int. J. Hydrogen Energy 2006, 31, 337-352. [CrossRef]

120. Thomas, C. Fuel cell and battery electric vehicles compared. Int. J. Hydrogen Energy 2009, 34, 6005-6020. [CrossRef]

121. Sharma, S.; Ghoshal, S.K. Hydrogen the future transportation fuel: From production to applications. Renew. Sustain. Energy Rev. 2015, 43, 1151-1158. [CrossRef]

122. Cox, K.E.; Williamson, K.D. Hydrogen: Its Technology and Implications; CRC Press: Boca Raton, FL, USA, 1979.

123. Schulte, I.; Hart, D.; van der Vorst, R. Issues affecting the acceptance of hydrogen fuel. Int. J. Hydrogen Energy 2004, 29, 677-685. [CrossRef]

124. Acar, C.; Dincer, I. Review and evaluation of hydrogen production options for better environment. J. Clean. Prod. 2019, 218, 835-849. [CrossRef] 